\title{
Family planning vouchers to improve delivery and uptake of contraception in low and middle income countries: A systematic review
}

Benjamin Bellows

Population Council

Ashish Bajracharya

Population Council

Carol Bulaya

Sophie Inambwae

Follow this and additional works at: https://knowledgecommons.popcouncil.org/departments_sbsr-rh

Part of the Demography, Population, and Ecology Commons, Family, Life Course, and Society Commons, International Public Health Commons, and the Women's Health Commons How does access to this work benefit you? Let us know!

\section{Recommended Citation}

Bellows, Benjamin, Ashish Bajracharya, Carol Bulaya, and Sophie Inambwae. 2015. "Family planning vouchers to improve delivery and uptake of contraception in low and middle income countries: A systematic review," Evidence Study Report. Lusaka: Population Council. 


\section{FAMILY PLANNING VOUCHERS} TO IMPROVE DELIVERY AND UPTAKE OF CONTRACEPTION IN LOW AND MIDDLE INCOME COUNTRIES: A SYSTEMATIC REVIEW

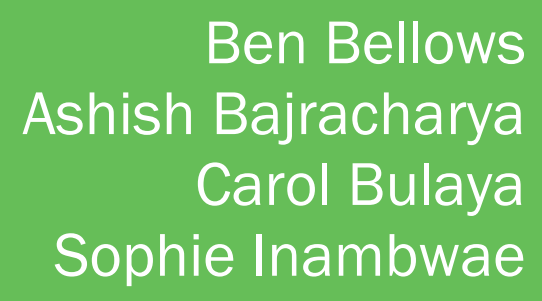


Population Council

Plot 3670, Four Mwaleshi Road

Lusaka

Zambia

10101

Tel: +260211295925

Fax: +260 211295925

E-mail: info.zambia@popcouncil.org

popcouncil.org

\section{POPULATION COUNCIL}

Ideas. Evidence. Impact.

The Population Council confronts critical health and development issues-from stopping the spread of HIV to improving reproductive health and ensuring that young people lead full and productive lives. Through biomedical, social science, and public health research in 50 countries, we work with our partners to deliver solutions that lead to more effective policies, programs, and technologies that improve lives around the world. Established in 1952 and headquartered in New York, the Council is a nongovernmental, non-profit organization governed by an international board of trustees.

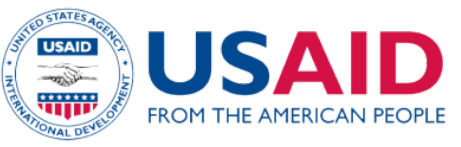

The Evidence Project is made possible by the generous support of the American people through the United States Agency for International Development (USAID) under the terms of cooperative agreement no. AID-OAA-A-13-00087. The contents of this document are the sole responsibility of the Evidence Project and Population Council and do not necessarily reflect the views of USAID or the United States Government.

\section{Evidence}

The Evidence Project uses implementation science-the strategic generation, translation, and use of evidence-to strengthen and scale up family planning and reproductive health programs to reduce unintended pregnancies worldwide. The Evidence Project is led by the Population Council in partnership with INDEPTH Network, International Planned Parenthood Federation, Management Sciences for Health, PATH, Population Reference Bureau, and a University Research Network.

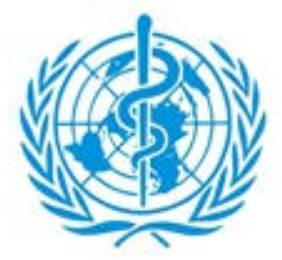

Suggested citation: Bellows, Ben, Ashish Bajracharya, Carol Bulaya and Sophie Inambwae. 2015. "Family Planning Vouchers to Improve Delivery and Uptake of Contraception in Low and Middle Income Countries: A Systematic Review". Lusaka, Zambia: Population Council.

(c) 2015 The Population Council, Inc. 


\section{Table of Contents}

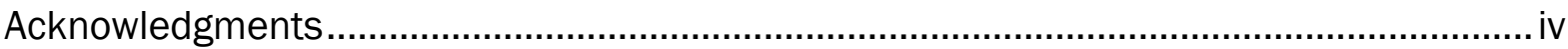

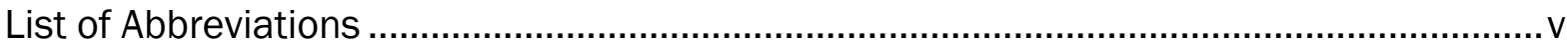

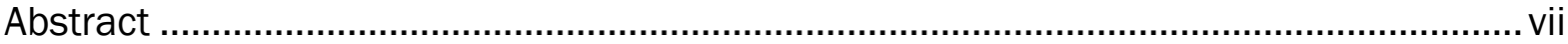

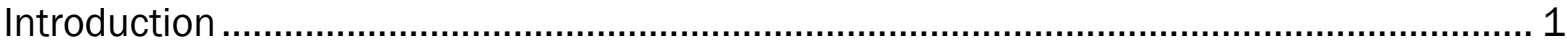

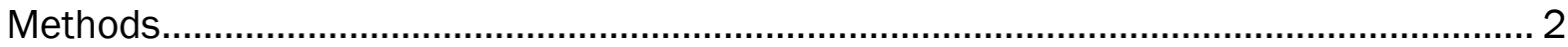

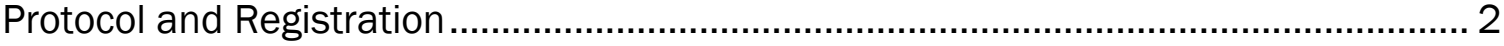

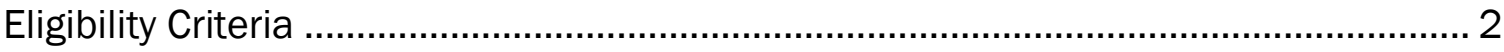

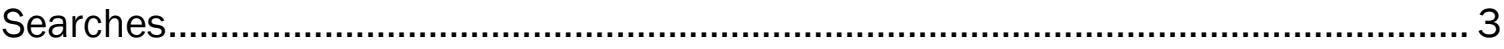

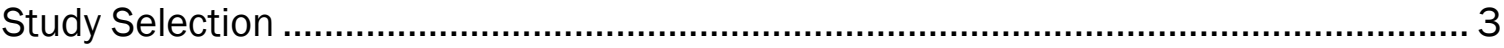

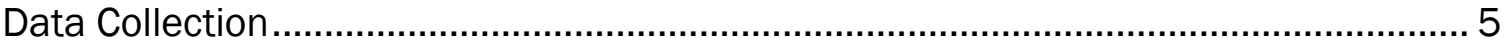

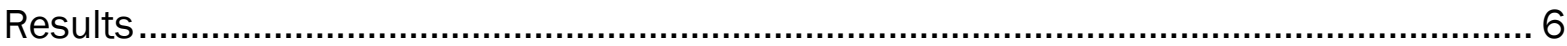

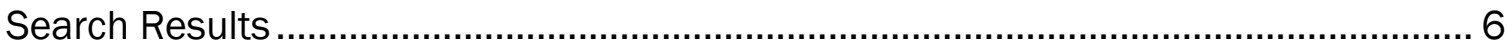

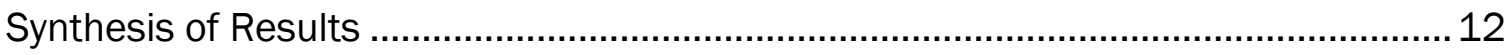

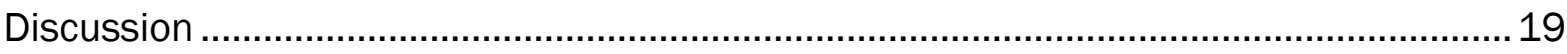

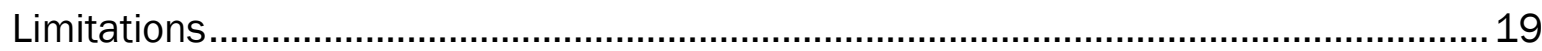

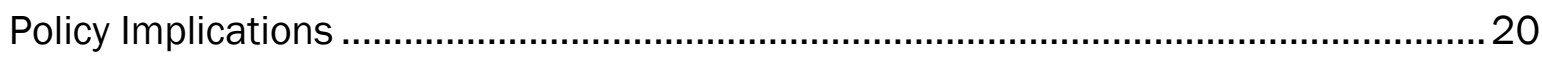

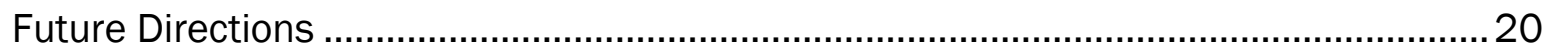

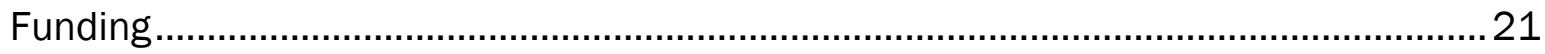

Author Contributions ....................................................................................... 21

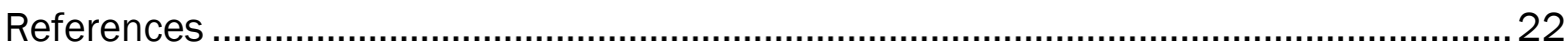




\section{Acknowledgments}

This study has been jointly supported by the World Health Organization's Department of Reproductive Health Research as well as the Evidence Project, a USAID-funded project utilizing implementation science to improve family planning and reproductive health, led by the Population Council. Dr. Moazzam Ali and Dr. Craig Louis Lissner from WHO led the development of a joint strategy for this comprehensive literature review on the impact of financial mechanisms on contraception. We extend our gratitude to them for their support throughout the study. Thanks also to the principal investigators and team members of other groups who conducted similar reviews on other financial mechanisms and provided fruitful inputs at meetings in Washington, DC, and Geneva. We thank Ellen Weiss of the Evidence project for her comments and editing. 


\section{Abbreviations}

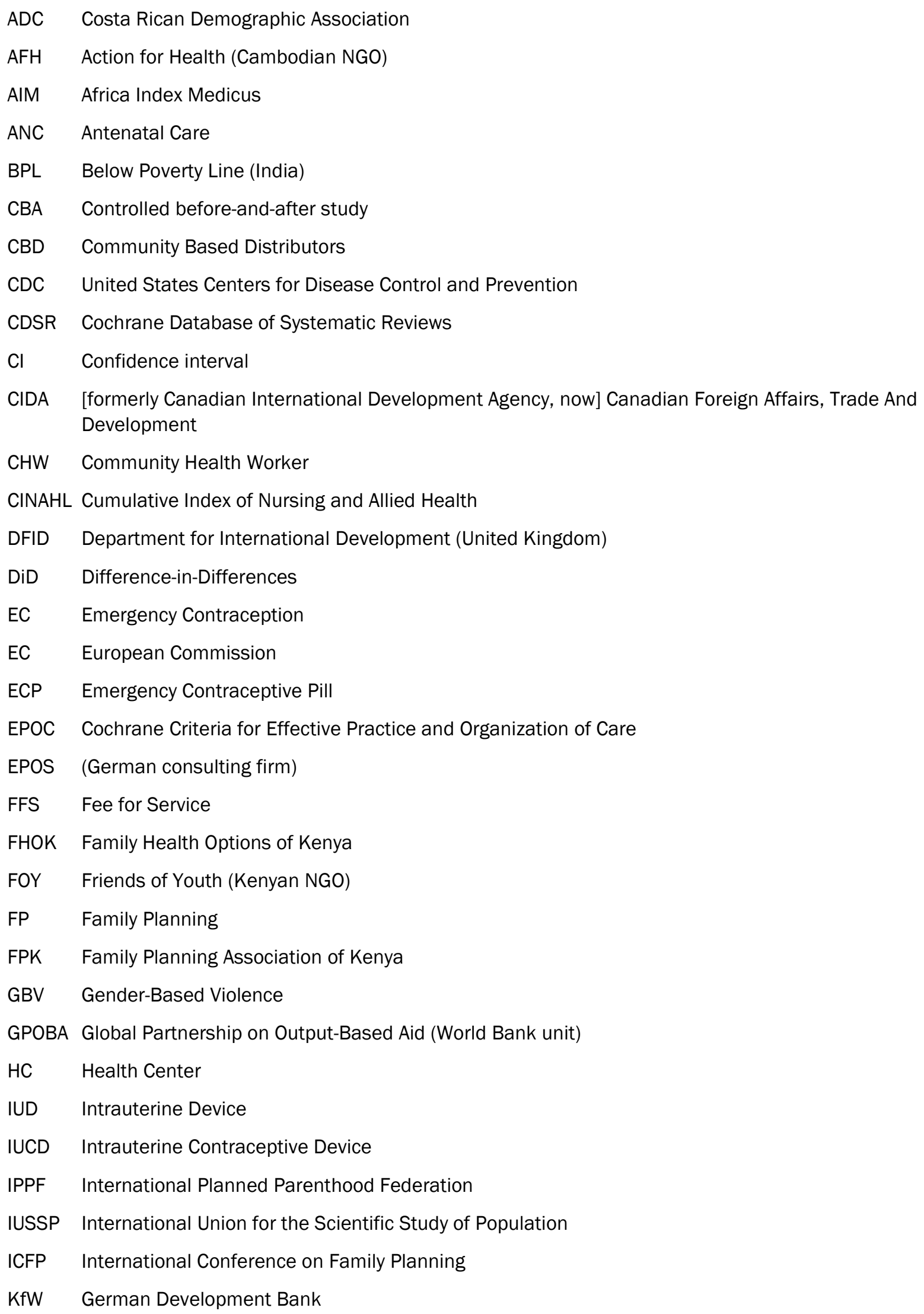



LAPM Long-Acting and Permanent Method
LARC Long-Acting and Reversible Contraception
MSI Marie Stopes International
OBA Output-Based Approach
OR Odds Ratio
OPM Oxford Policy and Management
NGO Non-governmental Organization
PAC Post-Abortion Care
PNC Postnatal Care
PNFP Postnatal Family Planning
PwC PriceWaterhouseCoopers
RCT Randomized Control Trial
$\mathrm{RH} \quad$ Reproductive Health
SRHC Sexual and Reproductive Health Care
SRH Sexual and Reproductive Health
SRHR Sexual and Reproductive Health and Rights
SMH Safe Maternal Health care
USAID United States Agency for International Development
UNFPA United Nations Population Fund
VIA Visual Inspection by Acid Acetic
VMA Voucher Management Agency
WRA Women of Reproductive Age 


\section{Abstract}

\section{Background}

Reproductive health vouchers have provided accessible and quality reproductive health services to the poor and have been critical for countries to make substantial progress in achieving Millennium Development Goal 5. Increased utilization of contraception allows for birth spacing, decreases unintended pregnancy, and results in healthier mothers and families. Strategies to improve utilization through targeted subsidies in low- and middle income countries have not been fully documented in a systematic review of the literature.

\section{Objective}

To summarize the effect of voucher systems for contraceptive services on client user socio-economic and demographic indicators in low- and middle income countries.

\section{Methods}

A systematic review of unpublished reports and published peer-reviewed articles in English using 33 databases (1960 to 2014) with key search terms was conducted. Additional studies were identified by contacting experts and searching bibliographies of citations identified during the systematic review. The keywords were drawn from three clusters or themes: a) low- and middle income countries, b) vouchers and health care financing, and c) family planning and contraception. Keywords used as search terms varied across databases and websites but the topical clusters remained a core factor in choice of keywords. Study designs included randomized control trials, cluster randomized control trials, controlled before-and-after (also termed quasi-experimental), interrupted time series analyses, cohort, and before-and-after studies. Methods of analysis and inclusion criteria were specified in a protocol registered on the PROSPERO database: CRD42015014149.

\section{Study Selection}

Studies designed with either a plausible comparison group or a credible counterfactual and reporting any of the primary outcomes were included.

\section{Data Extraction}

Two reviewers, using predefined data fields, independently extracted data from the first round of search results and, in a second round, extracted data from full length articles meeting the inclusion criteria.

\section{Data Analysis}

Data trends in studies were compared and summarized. The consistency in study design and outcome variable construction was not sufficient to allow results combination through meta-analysis.

\section{Results}

Fifteen reports met the inclusion criteria. Most reports were of studies with low quality designs, and only two had results from randomized control trials, while four had results from studies using controlled before-andafter designs. Four reports had results from before-and-after studies, and five reports presented results from cross-sectional studies.

\section{Conclusion}

This review has yielded important information on the effectiveness of voucher programs subsidizing contraceptive products and services. Voucher programs are intended to target subsidies to beneficiaries who, in the absence of the subsidy, would have had a lower probability of service utilization. In most studies, beneficiaries were defined by economic status; in two programs, adolescents were identified as disadvantaged and given vouchers. The current review found that contraceptive uptake did increase among the targeted beneficiaries in most studies. 
Vouchers demonstrate a productive mechanism for governments to engage private providers. Of the 31 programs identified in this review, 18 contracted only private providers, while seven other programs contracted a mix of public and private providers, and six engaged public providers only. The results suggest that voucher programs can expand client choice by reducing financial barriers to contraceptive services and make private providers an option for disadvantaged clients previously restricted by cost. 


\section{Introduction}

\section{BACKGROUND}

Since the 1960s more than 20 family planning (FP) programs in low- and middle income countries have used voucher subsidies to reach disadvantaged populations and improve access to contraception, particularly longacting methods (LAMs). Although the specifics vary between programs, generally the voucher strategy identifies beneficiaries from disadvantaged groups and gives individuals a voucher they can then take to a contracted public or private provider for service. In many programs, community-based distributors use a poverty grading tool consisting of household assets and amenities to identify poor women from their community who qualify for a voucher. Vouchers are redeemed for services at contracted health facilities. Facilities then submit their claims to a voucher management agency (VMA) for reimbursement of their costs of services to voucher clients. Although multiple studies have been published, there has not yet been a systematic review of the literature to summarize the effects of FP vouchers.

\section{RATIONALE}

Sexual and reproductive health and rights are central to people's lives and essential for their well-being. In practice, this means women and couples must have the means for a healthy sexual life, the number of children they want, when they want them, safe delivery of their babies, and survival of their newborns. Disparities among and within countries remain significant, however, and the poorest people face the greatest health challenges (Barros et al. 2012, Singh, Darroch, Ashford 2014). Family planning promotion is unique among health interventions in the breadth of its potential benefits: reduction of poverty, lower maternal and child mortality, women's empowerment, reduced burden of unwanted pregnancies, and strengthening environmental sustainability by stabilizing the planet's population (Cleland et al. 2006). To reduce disparities between rich and poor, many public health care professionals have become advocates for vouchers, which can be directed to poor people and then exchanged for health services (Boler and Harris 2010). This review of FP voucher programs will provide information about their effectiveness and efficiency in low- and middle income countries, and inform future development of FP voucher programs.

\section{OBJECTIVES}

To review and synthesize the evidence on the effectiveness of voucher systems for FP services in developing countries. 


\section{Methods}

\section{PROTOCOL AND REGISTRATION}

Analysis methods and inclusion criteria were specified in a protocol registered on the PROSPERO database: CRD42015014149 (www.crd.york.ac.uk/PROSPERO).

\section{ELIGIBILITY CRITERIA}

\section{Types of Studies}

We included quantitative studies presenting results for nine primary outcomes, in either before-and-after or controlled designs in peer-reviewed research publications or reports published in English. Well-constructed before-and-after studies without control groups or well-designed cross-sectional studies published in peerreviewed journals, or as working papers (grey literature), were also included. Excluded studies used a voucher simply to enroll participants (not subsidizing FP) or lacked a clear comparison or control group.

\section{Types of Participants}

Studies included in this review comprised samples of participants typically women of reproductive age (WRA), 15 to 49 years old, from poor or disadvantaged backgrounds in low- and middle income countries.

\section{Types of Interventions}

Interventions included were part of social protection programs providing a voucher subsidy to disadvantaged clients and reimbursed health care workers for contraceptive services at a pre-defined quality standard.

\section{Types of Outcome Measures}

Primary outcome measures:

i. Use of contraceptive services and/or commodities (utilization)

ii. Method continuation and switching

iii. New contraceptive users (targeting)

iv. Range of services (method mix)

v. Contraceptive prevalence (modern methods, overall, by method)

vi. Unmet need for contraceptives (modern methods)

vii. Unintended pregnancy

viii. Reduction of unsafe abortion

ix. Fertility: 1. Parity; 2. Completed fertility; 3. Timing of first birth; 4. Teenage births; 5 . Birth spacing.

\section{Information Sources}

Databases and online resources searched for published studies and unpublished grey literature were: PubMed; Popline; Cochrane Database of Systematic Reviews (CDSR); Cochrane Central Register of Controlled Trials (CENTRAL); IDEAS Economic database; Cumulative Index of Nursing and Allied Health (CINAHL); Science Direct; Inter-Science (Wiley); Africa Index Medicus (AIM); WHO Latin America and Caribbean (LILACS); WHO Southeast Asia (IMSEAR); WHO Eastern Mediterranean (IMEMR); WHO Western Pacific (WPRIM); African Heathline@Princeton University; Web of Science; Google Scholar; IUSSP; Population Reference Bureau; ELDIS; International Conference on Family Planning (ICFP) 2013; DfID; USAID; Canadian Foreign Affairs, Trade And Development, formerly CIDA; Population Council; Guttmacher Institute; London School of Hygiene and Tropical Medicine; Harvard University; Grey Literature (greylit.org); ResearchGate; African Journal Online; Center for 
Health Market Innovations; Social Franchising for Health; and University of California at Berkeley. One database (EMBASE) was not included due to restricted access.

The first strategy used key words in three topical clusters to help identify relevant literature: a) low- and middle income countries, b) vouchers and health care financing, and c) FP and contraception. Key words used as search terms varied by database and web sites, but the topical clusters remained a core factor of choice in key words (see Appendix 1 for specific key words by database).

\section{SEARCHES}

Two examples of key terms used in database searches and search strategies are:

\section{PubMed (Advanced Search)}

\section{Key Terms}

(developing countr* OR "poor countr*" OR "developing-countr*" OR "low-income countr*" OR "low-resource countr*" OR "low and middle income") AND (voucher* OR coupon* OR output-based* OR "output based" OR "results-based" OR results based* OR "performance-based*" OR "performance based" OR "pay-forperformance" OR "pay for performance" OR "demand side" OR demand-side OR financ*) AND ("family planning" OR contracept* OR "parity" OR "birth-spacing" OR birth spacing OR "birth-control" OR birth control OR condom* OR "method-mix" OR method mix OR "STIs")

Filtered by: Publication date from 1960/01/01 to 2014/12/31, Humans, English, Child: birth-18 years, Adult: 19+ years, Adult: 19-44 years, Aged: $65+$ years.

This yielded 244 initial results.

\section{INTER-WILEY (Advanced Search)}

Browse by: Subject>Social and Behavioral Sciences>Family and Child Studies

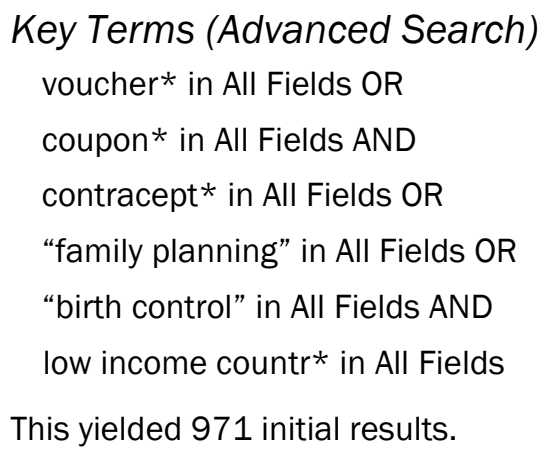

\section{STUDY SELECTION}

Study selection and grading involved two phases.

\section{Phase I: Inclusion/Exclusion}

In Phase I, abstracts of all studies identified in database searches were reviewed to determine whether studies should be included in the next phase of the review. Inclusion/exclusion criteria comprised:

Topic

Interventions to be included involved social protection programs offering a voucher subsidy to disadvantaged clients that reimbursed providers or facilities for contraceptive services with pre-defined quality standards. 
With limited studies identified in a preliminary qualitative search, inclusion criteria were extended to beforeand-after studies. Excluded studies lacked clear comparisons or control groups.

\section{Language}

Studies were required to be in English.

\section{Population}

Only articles focusing on populations in low- to middle income countries were included.

\section{Time Frame}

Articles published from 1960 to the present were included for further review. Our selection of 1960 as the terminus year was based on the historical development of modern contraceptives. Vouchers for FP prior to 1960 had limited methods for subsidizing.

\section{Type of Study}

Included studies were required to have credible comparative designs: randomized control trial (RCT), cluster RCT, controlled before-and-after (CBA), or interrupted time series; to increase included studies, before-andafter studies were also permitted.

The initial search yielded 5,894 articles from published and grey literature. Duplicates were removed and two reviewers screened the title and abstract of identified citations independently. From that screening process, 252 studies were identified for full article review.

\section{Expert Recommendations}

Marie Stopes shared 11 studies of RH voucher programs implemented in several countries; of those, nine had already been identified in the electronic database search. One recommendation was obtained from Population Council and another from a bibliography, resulting in three additional expert recommendations, which were manuscripts undergoing peer review. Of the three, two met the inclusion criteria.

\section{Phase II: Inclusion/Exclusion}

After identifying studies from bibliographic database searches, publishers' pages, relevant organizations, related research and programmatic networks, and expert feedback, we proceeded to Phase II of inclusion/ exclusion criteria. Full articles were read and included or excluded according to the following criteria:

\section{Country of Study}

Studies of voucher programs not in a low- or middle-income country were excluded.

\section{Primary Outcome}

To be included in Phase II, articles were required to examine at least one of the selected primary outcomes :

i. Use of contraceptive services and/or commodities (utilization)

ii. Continuation and switching

iii. New contraceptive users (targeting)

iv. Range of services (method mix)

v. Contraceptive prevalence (modern methods, overall, by method)

vi. Unmet need for contraceptives (modern methods)

vii. Unintended pregnancy

viii. Reduction of unsafe abortion

ix. Fertility: 1. Parity; 2. Completed fertility; 3. Timing of first birth; 4. Teenage births; 5 . Birth spacing 


\section{DATA COLLECTION}

For Phase II, we developed a data extraction form (Appendix 2) with 72 questions designed to extract information on the different aspects of the study and intervention. This was tested with five randomly selected articles, and refined accordingly. For each article included in Phase II, the researchers entered article information into a data extraction form. Data entered into the extraction form included information regarding the article's title, authors, publication date, source, study design, country, length of study, characteristics of population of interest, sampling frame, contraceptive methods, description of intervention, outcomes, funding sources, implementing partners, quality assessment and any additional notes.

\section{Data Items}

Information extracted from each study included: characteristics of the population (including socio-economic status, ethnic group, age group, parity, marital status or parity that is relevant to the study outcomes), type of intervention, duration of study, and outcome measures.

\section{Summary Measures}

The primary measures of effect included odds ratios, prevalence percentages, and incidence rates. Outcome variables were examined across studies, with the weight of evidence determined by the number of studies looking at common outcomes and the quality of study designs. A combination of results through meta-analysis could not be conducted since there was not sufficient consistency in study design and outcome variable construction. Instead, a narrative synthesis of the data was conducted.

After separate, parallel screening of the articles, the two research assistants discussed any discrepancies and together made a final judgment regarding inclusion or exclusion of the articles in question.

\section{Planned Methods of Analysis}

A descriptive analysis is undertaken drawing from the data from the systematic review. 


\section{Results}

\section{SEARCH RESULTS}

The search was conducted from March 2015 to May 2015. A total of 5,894 citations were identified from the electronic database search. After adjusting for duplicates, 3,872 remained. Of these, 3,620 studies were discarded because after reviewing the abstracts it appeared that these papers clearly did not meet the criteria. The full text of the remaining 252 citations was examined in more detail, and 227 studies did not meet the inclusion criteria as described. Fifteen sources met the inclusion criteria and were included in the systematic review. It is important to note that some sources reported more than one primary outcome of interest.

Figure 1 outlines the filtering process used to determine which studies would be included in the review. A total of 15 articles were included.

\section{FIGURE 1: Flow diagram illustrating the identification of studies included}

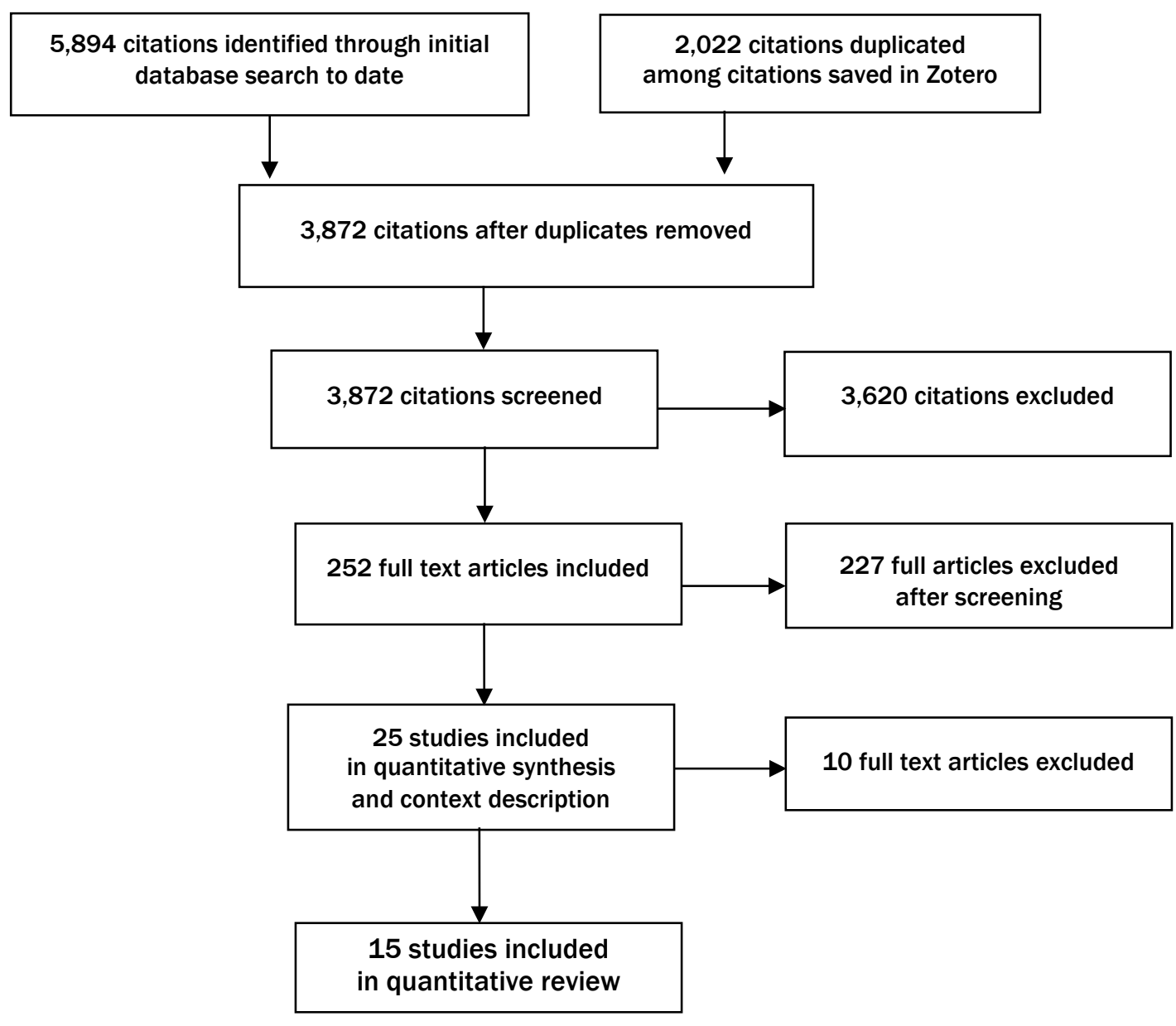

Of the 15 total sources included in the review, one source reported results from three different studies. Four other sources reported two outcomes within the scope of the review's primary outcomes.

The studies were of FP programs in 11 countries, with five in Africa, four in Asia, and two in Latin America. Ten studies were reported since 2010, three between 2000 and 2009, with one in the 1990s and one in the 1960s. 


\section{Characteristics of Included Studies}

\section{Methods}

Fifteen reports met the inclusion criteria. Most of the reports were of studies with low quality designs. Only two reports had results from RCTs. Four reports had results from studies using CBA designs. Four reports had results from before-and-after studies, and five reports presented results from cross-sectional studies.

All the identified studies were published in English. The duration of the interventions were approximately 24 months for CBA studies, 48 months for the before-and-after studies, and 12 months for RCTs. Studies presenting cross-sectional findings were drawn from programs of varying lengths, but given the cross-sectional design, attribution of effect was not possible. Several of the cross sectional studies reported findings from intervention data of less than a year in duration.

\section{Participants}

Study participants were most often women of reproductive age between 15 to 49 years old, often from poor or disadvantaged populations, with little or no access to FP services due to high cost or lack of availability of services in their location. Four studies were of programs that targeted married women. A program in Nicaragua provided vouchers to adolescents as young as 12 years of age for a range of SRHC.

\section{Intervention}

The intervention in each study was a voucher subsidy for WRA to access FP counseling and contraceptive services.

\section{Primary Outcomes}

In all studies the primary outcomes were assessed for any change from baseline to post-intervention after stated time interval of treatment:

i. Use of contraceptive services and/or commodities (utilization)

ii. Method continuation and switching

iii. New contraceptive users (targeting)

iv. Range of services (method mix)

v. Contraceptive prevalence (modern methods, overall, by method)

vi. Unmet need for contraceptives (modern methods)

vii. Unintended pregnancy

viii. Reduction of unsafe abortion

ix. Fertility: 1. Parity; 2. Completed fertility; 3. Timing of first birth; 4. Teenage births; 5. Birth spacing.

\section{Secondary Outcomes}

These included change in health outcomes, quality of care, cost effectiveness, and occurrences of any adverse effects. Characteristics of the included studies are presented in Table 1. 
TABLE 1: Summary of included studies evaluating use of family planning vouchers to improve delivery and uptake of contraception in low and middle income countries

\begin{tabular}{|c|c|c|c|c|c|c|c|c|c|c|}
\hline & Source & Country & $\begin{array}{c}\text { Type } \\
\text { of Study }\end{array}$ & $\begin{array}{l}\text { Participants, } \\
\text { Units } \\
\text { of } \\
\text { Observation }\end{array}$ & $\begin{array}{l}\text { Age } \\
\text { Range }\end{array}$ & Inclusion Criteria & Study Outcome & Time Frame & $\begin{array}{l}\text { Pre-Voucher, } \\
\text { Control } \\
\text { Group } \\
\text { Baseline } \\
\text { Value } \\
\end{array}$ & $\begin{array}{c}\text { Post- } \\
\text { Voucher, } \\
\text { Intervention } \\
\text { Group } \\
\text { Endline }\end{array}$ \\
\hline 1 & $\begin{array}{l}\text { BlueStar } \\
\text { Healthcare } \\
\text { Network Marie } \\
\text { Stopes } \\
\text { International } \\
\text { Viet Nam, } \\
2010\end{array}$ & Vietnam & $\begin{array}{l}\text { Before } \\
\text { and After }\end{array}$ & & $\begin{array}{l}13 \text { to } 24 \\
\text { years old }\end{array}$ & $\begin{array}{l}\text { Young adults and women } \\
\text { of the bottom } 20 \% \text { and lower- } \\
\text { middle income (20-40\%), } \\
\text { living in peri-urban and rural } \\
\text { areas at } 81 \text { franchised } \\
\text { facilities by } 2009 \text {. The pilot } \\
\text { began with } 32 \text { franchised } \\
\text { providers. }\end{array}$ & $\begin{array}{l}\text { Change in numbers } \\
\text { of inserted intrauterine } \\
\text { devices (IUDs) }\end{array}$ & 2008 to 2009 & $\begin{array}{l}\text { 1,892 IUDs } \\
(2008)\end{array}$ & $\begin{array}{c}\text { 5,988 IUDs } \\
\text { (2009) } \\
\text { Tests } \\
\text { of significance } \\
\text { not reported }\end{array}$ \\
\hline 2 & $\begin{array}{l}\text { Chang, Liu, \& } \\
\text { Chow, } 1969\end{array}$ & Taiwan & CBA & & $\begin{array}{l}20 \text { to } 44 \\
\text { years old }\end{array}$ & Matched married women & $\begin{array}{l}\text { Fertility rates (per 1000) } \\
\text { among IUD acceptors } \\
\text { before and after } \\
\text { intervention, matched } \\
\text { by parity to controls (non- } \\
\text { pregnant married women) }\end{array}$ & 1964 to 1968 & $-48 \%$ & $-80 \%^{\neq}$ \\
\hline 3.1 & $\begin{array}{l}\text { IFPS Technical } \\
\text { Assistance } \\
\text { Project (ITAP), } \\
2012\end{array}$ & Agra, India & $\begin{array}{l}\text { Before } \\
\text { and After }\end{array}$ & $\begin{array}{c}1983 \\
\text { (baseline) } \\
\text { and } 1463 \\
\text { (endline) } \\
\text { currently } \\
\text { married } \\
\text { women }\end{array}$ & $\begin{array}{l}15 \text { to } 49 \\
\text { years old }\end{array}$ & BPL rural married women & $\begin{array}{l}\text { Change in modern } \\
\text { contraceptive prevalence }\end{array}$ & 2006 to 2009 & $26.7 \%$ & $30.8 \%^{\neq \neq}$ \\
\hline 3.2 & $\begin{array}{l}\text { IFPS Technical } \\
\text { Assistance } \\
\text { Project (ITAP), } \\
2012\end{array}$ & $\begin{array}{l}\text { Kanpur } \\
\text { Nagar, India }\end{array}$ & $\begin{array}{l}\text { Before } \\
\text { and After }\end{array}$ & $\begin{array}{c}1428 \\
\text { (baseline) } \\
\text { and } 1280 \\
\text { (endline) } \\
\text { currently } \\
\text { married } \\
\text { women }\end{array}$ & $\begin{array}{l}15 \text { to } 49 \\
\text { years old }\end{array}$ & BPL slum married women & $\begin{array}{l}\text { Change in modern } \\
\text { contraceptive prevalence }\end{array}$ & 2006 to 2012 & $38.5 \%$ & $43.0 \%^{\neq \neq}$ \\
\hline 3.3 & $\begin{array}{l}\text { IFPS Technical } \\
\text { Assistance } \\
\text { Project (ITAP), } \\
2012\end{array}$ & $\begin{array}{l}\text { Haridwar, } \\
\text { India }\end{array}$ & $\begin{array}{l}\text { Before } \\
\text { and After }\end{array}$ & $\begin{array}{c}\text { 2133 } \\
\text { (baseline) } \\
\text { and 1324 } \\
\text { (endline) } \\
\text { currently } \\
\text { married } \\
\text { women }\end{array}$ & $\begin{array}{l}15 \text { to } 49 \\
\text { years old }\end{array}$ & BPL rural married women & $\begin{array}{l}\text { Change in modern } \\
\text { contraceptive prevalence }\end{array}$ & 2006 to 2009 & $32.8 \%$ & $43.1 \%^{\neq \neq}$ \\
\hline 4 & $\begin{array}{l}\text { Meuwissen, } \\
\text { Gorter, Kester } \\
\text { \& Knottnerus, } \\
2006\end{array}$ & Nicaragua & $\begin{array}{l}\text { Before } \\
\text { and After }\end{array}$ & $\begin{array}{l}19 \text { contracted } \\
\text { facilities that } \\
\text { treated } \\
\text { voucher } \\
\text { clients } \\
\end{array}$ & N/A & $\begin{array}{c}4 \text { public facilities } \\
10 \text { NGO facilities } \\
5 \text { private for profit facilities }\end{array}$ & $\begin{array}{c}\text { Change in percent } \\
\text { of simulated clients } \\
\text { received preferred } \\
\text { contraceptive method } \\
\text { with a receipt }\end{array}$ & 2000 to 2002 & $50 \%$ & $80 \%^{*}$ \\
\hline
\end{tabular}




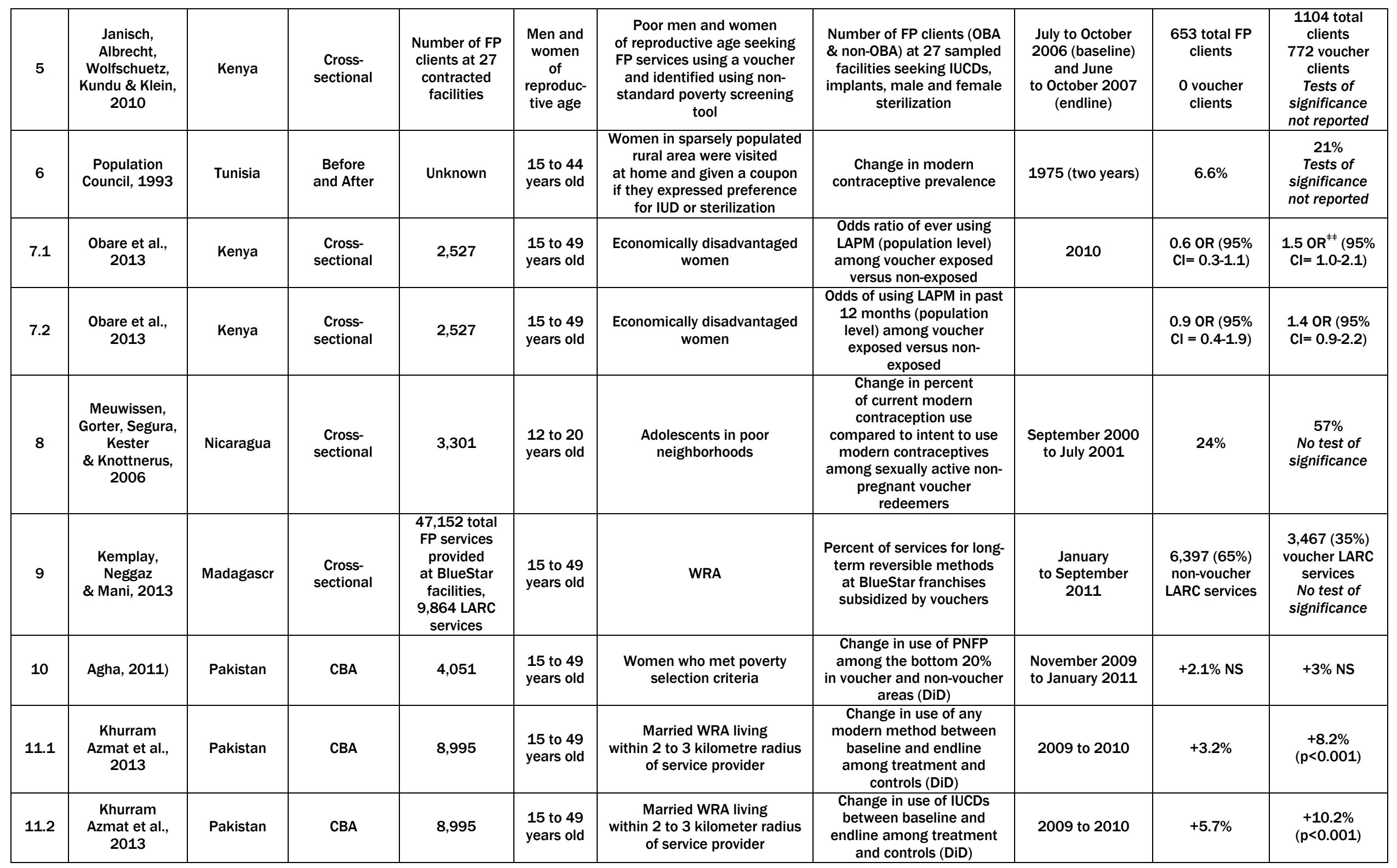




\begin{tabular}{|c|c|c|c|c|c|c|c|c|c|c|}
\hline 12 & $\begin{array}{l}\text { Meuwissen, } \\
\text { Gorter } \\
\text { \& Knottnerus, } \\
2006\end{array}$ & Nicaragua & $\begin{array}{l}\text { Cross- } \\
\text { sectional }\end{array}$ & 3,009 & $\begin{array}{l}12 \text { to } 20 \\
\text { years old }\end{array}$ & $\begin{array}{l}\text { Adolescents in poor } \\
\text { neighborhoods }\end{array}$ & $\begin{array}{l}\text { Use of SRHC over } 15 \\
\text { months }\end{array}$ & 2000 to 2001 & $\begin{array}{c}18.9 \% \\
\text { adolescents in } \\
\text { control used } \\
\text { SRHC }\end{array}$ & $\begin{array}{c}33.5 \% \\
\text { voucher } \\
\text { receivers used } \\
\text { SRHC } \\
\text { aOR }=3.07 \\
(95 \% \mathrm{Cl}= \\
2.45-3.84)\end{array}$ \\
\hline 13.1 & $\begin{array}{l}\text { Bajracharya, } \\
\text { Veasnakiry, } \\
\text { Rathavy } \\
\text { \& Bellows, } \\
2015\end{array}$ & Cambodia & CBA & 3,922 & $\begin{array}{l}18 \text { to } 45 \\
\text { years old }\end{array}$ & $\begin{array}{c}\text { Married WRA } \\
\text { with a 'poor card' ID }\end{array}$ & $\begin{array}{l}\text { Adjusted odd ratio of use } \\
\text { of LARC or permanent } \\
\text { method (PM) } \\
\text { among women currently } \\
\text { using any contraceptive } \\
\text { in voucher areas in the } \\
\text { post-intervention period } \\
\text { compared to women in pre- } \\
\text { or post-intervention control } \\
\text { groups or pre-intervention } \\
\text { treatment }\end{array}$ & 2011 to 2013 & $\begin{array}{l}+1.6 \% \\
\text { increased use } \\
\text { of LARC }\end{array}$ & $\begin{array}{c}+5.3 \% \\
\text { increased use } \\
\text { of LARC } \\
\\
3.32 \text { greater } \\
\text { odds to use a } \\
\text { LARC or a PM } \\
\text { [95\% C.I. } \\
=1.54-7.54] \\
(p<0.05) .\end{array}$ \\
\hline 13.2 & $\begin{array}{l}\text { Bajracharya } \\
\text { et al., } 2015\end{array}$ & Cambodia & CBA & 3,922 & $18-45$ & $\begin{array}{c}\text { Married WRA } \\
\text { with a 'poor card' ID }\end{array}$ & $\begin{array}{c}\text { Adjusted odds ratio } \\
\text { of modern contraceptive } \\
\text { use versus a traditional } \\
\text { method or not using } \\
\text { a method at all among all } \\
\text { women residing in voucher } \\
\text { areas in the intervention } \\
\text { period compared to women } \\
\text { in control areas or women } \\
\text { in treatment areas } \\
\text { during the pre-intervention } \\
\text { period }\end{array}$ & 2011 to 2013 & $\begin{array}{l}+5.8 \% \\
\text { increased use } \\
\text { of modern } \\
\text { contraception }\end{array}$ & $\begin{array}{c}+9.2 \% \\
\text { increased use } \\
\text { of modern } \\
\text { contraception } \\
\\
1.35 \text { greater } \\
\text { odds of using } \\
\text { a modern } \\
\text { contraceptive } \\
{[95 \% \text { C.l. }=} \\
1.00-1.81] \\
(p<0.05)\end{array}$ \\
\hline 14 & $\begin{array}{c}\text { Chin-Quee, } \\
\text { Wedderburn, } \\
\text { Otterness, } \\
\text { Janowitz } \\
\text { \& Chen-Mok, } \\
2010\end{array}$ & Jamaica & $\mathrm{RCT}$ & 1,008 & $\begin{array}{c}\text { Older } \\
\text { than } 16 \\
\text { years old }\end{array}$ & $\begin{array}{l}\text { Women purchasing } \\
\text { emergency contraceptive pills } \\
\text { (ECPs) }\end{array}$ & $\begin{array}{l}\text { Uptake of oral } \\
\text { contraceptive pills for more } \\
\text { than } 2 \text { months } \\
\text { with a voucher targeted } \\
\text { to EC consumers }\end{array}$ & 2006 to 2007 & $11 \%$ & $13 \% \mathrm{NS}$ \\
\hline 15.1 & $\begin{array}{c}\text { Ashraf, Field } \\
\text { \& Leight, } 2013\end{array}$ & Zambia & RCT & 1,664 & $\begin{array}{l}18 \text { to } 40 \\
\text { years old }\end{array}$ & $\begin{array}{l}\text { Married women in low- } \\
\text { income urban catchment of a } \\
\text { primary care clinic }\end{array}$ & $\begin{array}{l}\text { Probability of starting use } \\
\text { of modern contraception } \\
\text { (IUCD, injectables, pills, } \\
\text { implants) for first time } \\
\text { by endline }\end{array}$ & 2006 to 2007 & $7 \%$ & $25 \% \neq \neq$ \\
\hline 15.2 & $\begin{array}{c}\text { Ashraf et al., } \\
2013\end{array}$ & Zambia & RCT & 1,664 & $\begin{array}{l}18 \text { to } 40 \\
\text { years old }\end{array}$ & $\begin{array}{l}\text { Married women in low- } \\
\text { income urban catchment of a } \\
\text { primary care clinic }\end{array}$ & $\begin{array}{l}\text { Probability of using } \\
\text { injectable contraception } \\
\text { for first time by endline }\end{array}$ & 2006 to 2007 & $4 \%$ & $10 \%$ キ\# \\
\hline
\end{tabular}

\section{$\neq p<0.05$}

$\neq \neq p<0.01$

NS (not significant) 


\section{Quality of Studies}

Quality of the study designs was assessed using Cochrane criteria for Effective Practice and Organization of Care (EPOC) reviews for studies with a control group, i.e. RCTs and CBA studies (see Table 2).

Two research assistants independently assessed the risk of bias using the Cochrane EPOC group standard criteria for RCTs and CBA studies. They checked the adequacy of randomization and concealment of allocation, blinding of patients, health care providers, data collectors, and outcome assessors, and extent of loss to followup. A study supervisor arbitrated any discrepancies between research assistants. Studies using a before-andafter design and cross-sectional studies were not assessed for quality.

Of the 15 sources, nine reported results from a study design that lacked a comparison group, i.e. crosssectional and before-and-after designs. The other six sources reported results from RCT and CBA designs. Among the six sources, the two RCTs had a low aggregate risk of bias and the four CBAs had an unclear aggregate risk of bias (Table 2).

TABLE 2: Quality Measures and Risks of Bias in the Included RCT and CBA Studies

\begin{tabular}{|c|c|c|c|c|c|c|c|c|c|c|}
\hline & Design & $\begin{array}{l}\text { Allocation } \\
\text { Sequence } \\
\text { Generated }\end{array}$ & $\begin{array}{l}\text { Allocation } \\
\text { Sequence } \\
\text { Concealed }\end{array}$ & $\begin{array}{c}\text { Similar } \\
\text { Baseline } \\
\text { Outcome } \\
\text { Measurements } \\
\end{array}$ & $\begin{array}{c}\text { Addressing } \\
\text { Incomplete } \\
\text { Outcome } \\
\text { Data }\end{array}$ & $\begin{array}{c}\text { Prevention } \\
\text { of Knowledge } \\
\text { of Allocated } \\
\text { Interventions }\end{array}$ & $\begin{array}{c}\text { Protection } \\
\text { Against } \\
\text { Contamination }\end{array}$ & $\begin{array}{c}\text { Free } \\
\text { from } \\
\text { Selective } \\
\text { Reporting } \\
\end{array}$ & $\begin{array}{l}\text { Aggregate } \\
\text { Risk } \\
\text { of Bias }\end{array}$ & $\begin{array}{c}\text { Design } \\
\text { or Analysis } \\
\text { Limitations }\end{array}$ \\
\hline Agha,2011 & CBA & Low risk & Low Risk & High Risk & Unclear Risk & Unclear Risk & High Risk & $\begin{array}{l}\text { Unclear } \\
\text { Risk }\end{array}$ & $\begin{array}{c}\text { Unclear } \\
\text { Risk }\end{array}$ & None \\
\hline $\begin{array}{c}\text { Khurram } \\
\text { Azmat et al., } \\
2013\end{array}$ & CBA & Low Risk & Low Risk & Low Risk & Unclear Risk & Unclear Risk & Unclear Risk & $\begin{array}{l}\text { Unclear } \\
\text { Risk }\end{array}$ & $\begin{array}{l}\text { Unclear } \\
\text { Risk }\end{array}$ & $\begin{array}{c}\text { Measuring } \\
\text { or } \\
\text { controlling } \\
\text { for } \\
\text { important } \\
\text { confounding } \\
\text { variables } \\
\text { was difficult }\end{array}$ \\
\hline $\begin{array}{l}\text { Chin-Quee } \\
\text { et al., } 2010\end{array}$ & $\mathrm{RCT}$ & Low Risk & Low Risk & Low Risk & Low Risk & Low Risk & Low Risk & Low Risk & Low Risk & None \\
\hline $\begin{array}{l}\text { Ashraf et } \\
\text { al., } 2013\end{array}$ & RCT & Low Risk & Low Risk & Low Risk & Unclear Risk & Low Risk & Low Risk & Low Risk & Low Risk & None \\
\hline $\begin{array}{l}\text { Bajracharya } \\
\text { et al., } 2015\end{array}$ & CBA & $\begin{array}{l}\text { Unclear } \\
\text { Risk }\end{array}$ & $\begin{array}{l}\text { Unclear } \\
\text { Risk }\end{array}$ & Low Risk & Unclear Risk & Unclear Risk & Unclear Risk & $\begin{array}{l}\text { Unclear } \\
\text { Risk }\end{array}$ & $\begin{array}{c}\text { Unclear } \\
\text { Risk }\end{array}$ & $\begin{array}{c}\text { Possible } \\
\text { design } \\
\text { limitation } \\
\text { could have } \\
\text { been } \\
\text { spurious } \\
\text { associations } \\
\text { due } \\
\text { to } \\
\text { unobserved } \\
\text { confounders }\end{array}$ \\
\hline $\begin{array}{l}\text { (Chang, Liu, } \\
\text { \& Chow, } \\
\text { 1969) }\end{array}$ & CBA & Low risk & $\begin{array}{l}\text { Unclear } \\
\text { Risk }\end{array}$ & Low Risk & Unclear Risk & Unclear Risk & Unclear Risk & $\begin{array}{l}\text { Unclear } \\
\text { Risk }\end{array}$ & $\begin{array}{l}\text { Unclear } \\
\text { Risk }\end{array}$ & $\begin{array}{l}\text { Effective } \\
\text { design } \\
\text { hinged on } \\
\text { matching } \\
\text { procedure }\end{array}$ \\
\hline
\end{tabular}

\section{Family Planning Outcome Variables}

Table 1 lists the FP outcomes extracted from the included sources. Although there were nine primary outcomes of interest, only two types of outcomes were quantified in the literature: 1) utilization of contraceptives and 2) changes to fertility, primarily fertility rates. A third outcome (contraceptive continuation) was mentioned in a study that noted no difference between women who accessed IUDs using a voucher and similar women accessing IUDs without a voucher, but numbers were not provided (Azmat et al. 2012). 
Specific contraceptives adopted in each study varied. All programs under study offered a mix of short term and long term methods, with vouchers frequently subsidizing higher cost long term methods, particularly implants and IUDs. One RCT in Jamaica tested the effect of vouchers on emergency contraception (EC).

From the 15 sources, a total of 21 outcome variables were extracted with 20 outcomes grouped under contraceptive uptake or level, and one as fertility changes. Of the 20 outcome variables on contraceptive uptake or level, 17 reported an increase or higher level of contraceptive use among the voucher exposed group; however, four studies failed to test for significance. Three studies found no significant difference in the positive trends of control and voucher groups. No studies reported a decreased utilization or lower contraceptive levels in the voucher group. The one study of fertility rates observed a statistically significant decrease in fertility in the voucher-exposed population.

\section{SYNTHESIS OF RESULTS}

Of the six studies with high quality designs (two RCTs and four CBAs), reported results were generally positive. Of the two RCTs, one found a statistically strong association between voucher use and IUD uptake, and the other found no effect between vouchers and uptake of EC. Among the four controlled before-and-after studies, there were six reported outcomes with two non-significant changes in contraceptive use among the general population and PNC clients, three significant increases in contraceptive use, and one significant decrease in fertility. 
TABLE 3: Country Programs of Included Studies

\begin{tabular}{|c|c|c|c|c|c|c|c|c|c|c|c|c|}
\hline Country & Donor(s) & $\begin{array}{l}\text { Donor } \\
\text { Type }\end{array}$ & $\begin{array}{c}\text { VMA } \\
\text { Partners }\end{array}$ & $\begin{array}{l}\text { VMA } \\
\text { Partner } \\
\text { Type }\end{array}$ & $\begin{array}{c}\text { Service } \\
\text { Provider } \\
\text { (Private, } \\
\text { Public) }\end{array}$ & $\begin{array}{l}\text { Beneficiary } \\
\text { Type }\end{array}$ & $\begin{array}{l}\text { Providers } \\
\text { (Maximum) }\end{array}$ & $\begin{array}{l}\text { Voucher } \\
\text { Price }\end{array}$ & $\begin{array}{l}\text { Transport } \\
\text { Covered? }\end{array}$ & $\begin{array}{c}\text { Verification } \\
\text { in Program? }\end{array}$ & $\begin{array}{c}\text { Reimbursement } \\
\text { Amounts } \\
\text { to Providers }\end{array}$ & $\begin{array}{c}\text { Type } \\
\text { of Marketing }\end{array}$ \\
\hline Cambodia & KfW & $\begin{array}{l}\text { Bilateral } \\
\text { Agency }\end{array}$ & $\begin{array}{l}\text { EPOS, AfH, } \\
\text { PWC }\end{array}$ & $\begin{array}{l}\text { For Profit, } \\
\text { NGO }\end{array}$ & $\begin{array}{l}\text { Public } \\
\text { and } \\
\text { Private }\end{array}$ & $\begin{array}{l}\text { Means Tested } \\
\text { and } \\
\text { Geographic }\end{array}$ & 20 & Free & Yes & Yes & $\begin{array}{c}\text { Flat Rate: } \\
\text { ANC/PNC } 1 \text { US\$. } \\
\text { FP Counseling } 2 \\
\text { US\$. } 10 \text { US\$ ND. } \\
60 \text { US\$ CS. } 20 \\
\text { US\$ Compl.15 US\$ } \\
\text { abortion. } 7 \text { IUD, } 10 \\
\text { Implants } 25 \text { Ster. }\end{array}$ & $\begin{array}{c}\text { Community- } \\
\text { based } \\
\text { distributors } \\
\text { identified } \\
\text { eligible WRA } \\
\text { with ID 'poor } \\
\text { card' }\end{array}$ \\
\hline Kenya & KfW & $\begin{array}{l}\text { Bilateral } \\
\text { Agency }\end{array}$ & PWC & For Profit & $\begin{array}{l}\text { Public } \\
\text { and } \\
\text { Private }\end{array}$ & $\begin{array}{l}\text { Means Tested } \\
\text { and } \\
\text { Geographic }\end{array}$ & 78 & Free & No & Yes & Not Stated & $\begin{array}{c}\text { Phase I } \\
\text { distributors } \\
\text { from (NGOs) } \\
\text { were used, } \\
\text { received a } \\
\text { commission for } \\
\text { each voucher. } \\
\text { Phase II } \\
\text { through } \\
\text { salaried } \\
\text { distributors }\end{array}$ \\
\hline Pakistan & MSI & $\begin{array}{l}\text { Bilateral } \\
\text { Agency }\end{array}$ & $\begin{array}{l}\text { Private } \\
\text { Service } \\
\text { Providers }\end{array}$ & For profit & Private & Means Tested & 16 & $\begin{array}{l}200 \\
\text { Pk. R.s } \\
\text { (US \$2.27) } \\
\text { for IUCD } \\
\text { Only }\end{array}$ & No & No & $\begin{array}{c}\text { Pk. R.s } 200 \\
\text { per Provider } \\
\text { for Insertion (150), } \\
\text { Follow Up (20), } \\
\text { Removal (30) }\end{array}$ & $\begin{array}{c}\text { Providers } \\
\text { branded 'Suraj' } \\
\text { clinics, } \\
\text { marketing } \\
\text { through FWM, } \\
\text { posters, wall } \\
\text { paintings, } \\
\text { leaflets, door- } \\
\text { to-door } \\
\text { marketing } \\
\text { by FWs }\end{array}$ \\
\hline Madagascar & $\begin{array}{c}\text { SHOPS, } \\
\text { Abt } \\
\text { Associates }\end{array}$ & Multilateral & $\begin{array}{l}\text { Banyan } \\
\text { Global } \\
\text { Jhpiego, } \\
\text { MSI, } \\
\text { Monitor } \\
\text { Group, } \\
\text { O'Hanlon } \\
\text { Health } \\
\text { Consulting }\end{array}$ & For Profit & Private & Means Tested & 50 & $\begin{array}{l}\text { Ar. 1,000 } \\
\text { Average } \\
\text { Cost }\end{array}$ & No & Yes & $\begin{array}{l}\text { Flat Rate, } \\
\text { Not Stated }\end{array}$ & $\begin{array}{l}\text { CHWs receive } \\
\text { fixed stipend } \\
\text { for voucher } \\
\text { distribution }\end{array}$ \\
\hline
\end{tabular}




\begin{tabular}{|c|c|c|c|c|c|c|c|c|c|c|c|c|}
\hline & & & $\begin{array}{l}\text { National } \\
\text { Family } \\
\text { Planning } \\
\text { Board, } \\
\text { Medimpex }\end{array}$ & & & & & & & & & \\
\hline Zambia & $\begin{array}{c}\text { National } \\
\text { Science } \\
\text { Foundation, } \\
\text { Hewlett } \\
\text { Foundation, } \\
\text { Women \& } \\
\text { Public Policy } \\
\text { Program } \\
\text { at Harvard }\end{array}$ & Multilateral & $\begin{array}{l}\text { Society } \\
\text { for Family } \\
\text { Health }\end{array}$ & NGO & Public & Means Tested & 1 & Free & No & Yes & N/A & None \\
\hline Nicaragua & DfID & Bilateral & ICAS & NGO & $\begin{array}{l}\text { Public } \\
\text { and } \\
\text { Private }\end{array}$ & Means Tested & 20 & Free & No & No & $\begin{array}{l}\text { Agreed Fee, } \\
\text { Not Stated }\end{array}$ & $\begin{array}{c}\text { Distribution } \\
\text { in poor } \\
\text { Mangua } \\
\text { neighborhoods }\end{array}$ \\
\hline Pakistan & PSI & Bilateral & $\begin{array}{l}\text { Greenstar } \\
\text { Social } \\
\text { Marketing }\end{array}$ & $\begin{array}{c}\text { NGO, } \\
\text { For Profit }\end{array}$ & Private & Means Tested & & $\begin{array}{l}\text { Rs. } 100 \\
\text { (US \$1.20) }\end{array}$ & Yes & Yes & $\begin{array}{c}\text { R.s } 100 \text { for } 3 \text { ANC } \\
\text { visits, } \\
\text { R.s } 2,200 \text { (US } \$ 26 \text { ) } \\
\text { combined normal } \\
\text { delivery and } \\
\text { PNC visit, FP visit } \\
\text { R.s } 100 \text { (\$1.2). }\end{array}$ & $\begin{array}{l}\text { targeting } \\
\text { by project } \\
\text { outreach } \\
\text { workers }\end{array}$ \\
\hline Tunisia & Government & National & $\begin{array}{l}\text { National } \\
\text { Family } \\
\text { Planning } \\
\text { Program }\end{array}$ & Government & Public & Means Tested & None & Free & No & No & N/A & $\begin{array}{l}\text { Household } \\
\text { distribution }\end{array}$ \\
\hline Vietnam & $\begin{array}{l}\text { MSI, } \\
\text { AusAID, } \\
\text { IPPF }\end{array}$ & Bilateral & Bluestar & $\begin{array}{c}\text { NGO, } \\
\text { For Profit }\end{array}$ & Private & Means Tested & 81 & $\begin{array}{c}\text { IUD } \\
\text { US } \$ 5.40- \\
\$ 8.40 \\
\text { Abortion } \\
\text { US } \$ 11- \\
\$ 16.25\end{array}$ & No & Yes & $\begin{array}{l}\text { IUD } 30,000 \text { dong } \\
\text { (US \$1.63) }\end{array}$ & $\begin{array}{c}\text { BlueStar } \\
\text { poster, } \\
\text { branding and } \\
\text { IEC materials } \\
\text { for franchisees }\end{array}$ \\
\hline India & $\begin{array}{l}\text { USAID, } \\
\text { IFPS }\end{array}$ & Bilateral & $\begin{array}{c}\text { Futures } \\
\text { Group- } \\
\text { India, } \\
\text { Bearing } \\
\text { Point, } \\
\text { Sibley } \\
\text { Int'l., } \\
\text { Johns } \\
\text { Hopkins } \\
\text { University }\end{array}$ & $\begin{array}{c}\text { NGO, } \\
\text { For Profit }\end{array}$ & Private & Means Tested & 31 & Free & Yes & Yes & $\begin{array}{c}\text { R.s } 100 \text { for } 2 \text { PNC } \\
\text { visits, } \\
\text { R.s } 1500 \\
\text { for sterilization, } \\
\text { R.s } 300 \text { for IUCD }\end{array}$ & $\begin{array}{l}\text { Street plays } \\
\text { and } 50 \text { haat } \\
\text { (weekly } \\
\text { markets) }\end{array}$ \\
\hline
\end{tabular}


TABLE 4: Country Programs of Included Studies

\begin{tabular}{|c|c|c|c|c|c|c|c|c|c|c|c|c|c|c|c|c|c|}
\hline & Country & Program & Donor(s) & $\begin{array}{l}\text { Donor } \\
\text { Type }\end{array}$ & $\begin{array}{l}\text { Initiated } \\
\text { by }\end{array}$ & Years & $\begin{array}{c}\text { VMA } \\
\text { Partners }\end{array}$ & $\begin{array}{l}\text { VMA } \\
\text { Partner } \\
\text { Type }\end{array}$ & $\begin{array}{l}\text { Service } \\
\text { Providers }\end{array}$ & Beneficiaries & $\begin{array}{l}\text { Services } \\
\text { Covered }\end{array}$ & $\begin{array}{c}\text { Providers } \\
\text { (Maximum) }\end{array}$ & $\begin{array}{l}\text { Voucher } \\
\text { Price }\end{array}$ & $\begin{array}{l}\text { Transport } \\
\text { Covered? }\end{array}$ & $\begin{array}{l}\text { Verification } \\
\text { in } \\
\text { Program? }\end{array}$ & $\begin{array}{c}\text { Reimbursement } \\
\text { Amounts } \\
\text { to Providers }\end{array}$ & $\begin{array}{c}\text { Type } \\
\text { of Marketing }\end{array}$ \\
\hline 1 & Bangladesh & $\begin{array}{l}\text { MSCS Voucher } \\
\text { Scheme } \\
\text { Bangladesh }\end{array}$ & $\begin{array}{l}\text { European } \\
\text { Commission }\end{array}$ & $\begin{array}{l}\text { Bilateral } \\
\text { Agency }\end{array}$ & $\begin{array}{c}\text { Social } \\
\text { Franchise, } \\
\text { MSI }\end{array}$ & $\begin{array}{l}2006 \\
\text { to } 2010\end{array}$ & MSCS & NGO & $\begin{array}{c}\text { Public } \\
\text { and Private }\end{array}$ & $\begin{array}{l}\text { Poor Pregnant } \\
\text { Women }\end{array}$ & $\begin{array}{c}\text { At Least Two } \\
\text { ANC Visits, One } \\
\text { Pregnancy } \\
\text { Hospital } \\
\text { Admittance } \\
\text { and Delivery } \\
\text { (normal and } \\
\text { caesarean) } \\
\text { with Any } \\
\text { Medicine } \\
\text { or Treatment, } \\
\text { and One PNC } \\
\text { Check Up, } \\
\text { Travel to and } \\
\text { from Clinic }\end{array}$ & 13 & Free & Yes & Yes & $\begin{array}{l}\text { Flat Rate: } \\
\text { Taka } 3100 \\
\text { for Normal Delivery } \\
\text { and Taka } 7500 \\
\text { for Caesarian }\end{array}$ & $\begin{array}{l}\text { Volunteers visit } \\
\text { pregnant } \\
\text { mothers, } \\
\text { advocacy forums }\end{array}$ \\
\hline 2 & $\begin{array}{l}\text { Cambodia } \\
\text { UNFPA }\end{array}$ & $\begin{array}{l}\text { Health Equity Fund } \\
\text { for Reproductive } \\
\text { Health }\end{array}$ & UNFPA & $\begin{array}{l}\text { Multilateral } \\
\text { Agency }\end{array}$ & UNFPA & $\begin{array}{l}2008 \\
\text { to } 2010\end{array}$ & $\begin{array}{c}\text { District } \\
\text { Health } \\
\text { Financing } \\
\text { Steering } \\
\text { Committee } \\
\text { (DHFSC) }\end{array}$ & NGO & Public Only & $\begin{array}{l}\text { Poor Women } \\
\text { and Couples }\end{array}$ & $\begin{array}{l}\text { RH, FP, SMH, } \\
\text { PAC, SRH: FP, } \\
\text { SMH, PosTD, } \\
\text { PMTCT }\end{array}$ & - & Free & $\begin{array}{l}\text { Yes, for } \\
\text { referral }\end{array}$ & Yes & Normal User Fees & - \\
\hline 3 & $\begin{array}{l}\text { Cambodia } \\
\text { KFW }\end{array}$ & $\begin{array}{c}\text { Vouchers } \\
\text { for Reproductive } \\
\text { Health Services }\end{array}$ & $\mathrm{kfW}$ & $\begin{array}{l}\text { Bilateral } \\
\text { Agency }\end{array}$ & $\mathrm{kfW}$ & $\begin{array}{c}2011 \\
\text { to Present }\end{array}$ & $\begin{array}{l}\text { EPOS Health } \\
\text { Consultants, } \\
\text { OPM, PWC, } \\
\text { AFH }\end{array}$ & NGO & Public & \begin{tabular}{|c|} 
FP: Poor Men \\
and Women \\
of Reproductive \\
Age, Poor \\
Pregnant \\
Women, Poor \\
and Non-poor \\
Women \\
for Safe Abortion \\
\end{tabular} & $\begin{array}{l}\text { SMH, FP, } \\
\text { Abortion, } \\
\text { Long and } \\
\text { Short Term FP }\end{array}$ & $\begin{array}{c}70 \text { to } 80 \mathrm{HCs}, \\
5 \text { to } 10 \text { referral } \\
\text { hospitals, } \\
\text { a few private } \\
\text { facilities }\end{array}$ & Free & Yes & Yes & Not Stated & - \\
\hline 4 & $\begin{array}{l}\text { Cambodia } \\
\text { MSI }\end{array}$ & $\begin{array}{l}\text { Vouchers Scheme } \\
\text { for Reproductive } \\
\text { Health } \\
\text { in Cambodia }\end{array}$ & $\begin{array}{l}\text { EC, AusAID, } \\
\text { USAID }\end{array}$ & $\begin{array}{l}\text { Multilateral } \\
\text { Agency }\end{array}$ & $\begin{array}{l}\text { Social } \\
\text { Franchise, } \\
\text { MSI }\end{array}$ & $\begin{array}{c}2010 \\
\text { to } 2012\end{array}$ & $\begin{array}{c}\text { MSI } \\
\text { Cambodia }\end{array}$ & NGO & $\begin{array}{c}\text { Public } \\
\text { and Private }\end{array}$ & $\begin{array}{l}\text { Poor Rural } \\
\text { Women }\end{array}$ & $\begin{array}{l}\text { FP, IUD, } \\
\text { Tubal Ligation, } \\
\text { Vasectomy }\end{array}$ & 43 & Free & No & - & Not Stated & $\begin{array}{l}\text { Village Health } \\
\text { Support Groups } \\
\text { awareness- } \\
\text { raising } \\
\text { campaigns }\end{array}$ \\
\hline 5 & Colombia & Profamilia & $\begin{array}{l}\text { USAID, State } \\
\text { Government }\end{array}$ & $\begin{array}{l}\text { Bilateral } \\
\text { agency }\end{array}$ & $\begin{array}{l}\text { Fernando } \\
\text { Tamayo }\end{array}$ & $\begin{array}{l}1966 \\
\text { to Present }\end{array}$ & IPPF & NGO & Private & $\begin{array}{c}\text { Youth } \\
\text { (ages 10-19), } \\
\text { Men and Women }\end{array}$ & $\begin{array}{c}\text { SRH, } \\
\text { Contraception, } \\
\text { Gynecological } \\
\text { Exams, } \\
\text { Pregnancy and } \\
\text { STI Testing, } \\
\text { Abortion, } \\
\text { Cervical and } \\
\text { Breast Cancer } \\
\text { Screenings }\end{array}$ & 66 & - & No & Yes & \begin{tabular}{|c|} 
Initial distributor \\
keeps half of price \\
in return for services, \\
now services \\
reimbursed through \\
government's health \\
insurance scheme and \\
subsidized between \\
85 and $90 \%$
\end{tabular} & $\begin{array}{c}\text { Communication } \\
\text { and motivation } \\
\text { by female field } \\
\text { workers, online } \\
\text { sexual education, } \\
\text { IEC material }\end{array}$ \\
\hline 6 & Costa Rica & $\begin{array}{c}\text { Costa Rican } \\
\text { Demographic } \\
\text { Association (ADC) }\end{array}$ & IPPF & $\begin{array}{l}\text { Bilateral } \\
\text { Agency }\end{array}$ & $\begin{array}{l}\text { Alberto } \\
\text { Gonzalez }\end{array}$ & 1 & - & - & Private & WRA & $\begin{array}{c}\text { Oral } \\
\text { contraceptives }\end{array}$ & $123(1972)$ & $\begin{array}{l}3 \text { colone } \\
\text { (US } 35 \phi) \\
\text { or free } \\
\text { in } 1972 \\
\text { depending } \\
\text { on ability } \\
\text { to pay } \\
\end{array}$ & No & Yes & $\begin{array}{l}25 \text { to } 30 \% \text { or markup } \\
\text { (US 30-50\%) in } 1972\end{array}$ & $\begin{array}{l}\text { Recruitment } \\
\text { by national } \\
\text { campaigns }\end{array}$ \\
\hline 7 & China & $\begin{array}{l}\text { China Basic Health } \\
\text { Services Project }\end{array}$ & World Bank & $\begin{array}{l}\text { Multilateral } \\
\text { Agency }\end{array}$ & $\begin{array}{l}\text { Government, } \\
\text { World Bank }\end{array}$ & $\begin{array}{l}2005 \\
\text { to } 2007\end{array}$ & Government & NGO & Public & Poor People & $\begin{array}{c}\text { RTIs, MCH, } \\
\text { hypertension, } \\
\text { immunization }\end{array}$ & & & & & & \\
\hline 8 & $\begin{array}{l}\text { Dominican } \\
\text { Republic }\end{array}$ & Red Segura & $\begin{array}{l}\text { KfW, USAID, } \\
\text { Ministry } \\
\text { of Health }\end{array}$ & $\begin{array}{l}\text { Bilateral } \\
\text { Agency }\end{array}$ & PSI & $\begin{array}{c}\text { October } \\
2013 \\
\text { to Present }\end{array}$ & - & - & Private & \begin{tabular}{|c|} 
Young Adults \\
(ages 13-24), \\
Men, Women, \\
Adults \\
of Bottom, \\
Lower, Middle \\
Income Brackets \\
\end{tabular} & & 5 & - & - & - & - & - \\
\hline
\end{tabular}




\begin{tabular}{|c|c|c|c|c|c|c|c|c|c|c|c|c|c|c|c|c|c|}
\hline 9 & Ethiopia & Ethiopia Blue Star & $\begin{array}{c}\text { Royal } \\
\text { Netherlands } \\
\text { Government, } \\
\text { DfID, USAID, } \\
\text { Large } \\
\text { Anonymous } \\
\text { Donor }\end{array}$ & $\begin{array}{l}\text { Bilateral } \\
\text { Agency }\end{array}$ & MSI & \begin{tabular}{|l|}
2008 \\
to Present
\end{tabular} & - & - & Private & $\begin{array}{l}\text { Young Adults } \\
\text { (ages 13-24), } \\
\text { Men, Women, } \\
\text { Military } \\
\text { of Bottom, } \\
\text { Lower, Middle } \\
\text { Income Brackets }\end{array}$ & $\begin{array}{l}\text { FP, HIV/AIDS, } \\
\text { PAC, } \\
\text { Safe Abortion, } \\
\text { Other Services }\end{array}$ & 585 & - & - & Yes & - & - \\
\hline 10 & $\begin{array}{l}\text { India, } \\
\text { Agra, UP }\end{array}$ & $\begin{array}{l}\text { Agra Voucher } \\
\text { Scheme, } \\
\text { Developed } \\
\text { by Sambhav } \\
\text { Branding } \\
\end{array}$ & USAID & $\begin{array}{l}\text { Bilateral } \\
\text { Agency }\end{array}$ & $\begin{array}{l}\text { USAID, } \\
\text { State } \\
\text { Government }\end{array}$ & \begin{tabular}{|l|}
2007 \\
to Present
\end{tabular} & \begin{tabular}{|c|} 
District \\
Project \\
Management \\
Unit \\
(DPMU) \\
\end{tabular} & NGO & Private & $\begin{array}{l}\text { Married Women } \\
\text { (ages 15-49), } \\
\text { Men of Bottom } \\
20 \% \text { Income }\end{array}$ & $\begin{array}{l}\text { SMH, FP, } \\
\text { RTI/STI, } \\
\text { Long Term FP }\end{array}$ & 148 & Free & Yes & Yes & $\begin{array}{c}\text { Negotiated, } \\
\text { Rates at } 35 \text { to } 50 \% \\
\text { Below Market Prices }\end{array}$ & $\begin{array}{c}\text { Branding, } \\
\text { leaflets, house } \\
\text { visits by } \\
\text { Accredited Social } \\
\text { Health Activists } \\
\end{array}$ \\
\hline 11 & $\begin{array}{c}\text { India, } \\
\text { Kanpur, UP }\end{array}$ & Sambhav & USAID & $\begin{array}{l}\text { Bilateral } \\
\text { Agency }\end{array}$ & $\begin{array}{l}\text { USAID, } \\
\text { State } \\
\text { Government }\end{array}$ & $\begin{array}{c}2006 \\
\text { to } 2012\end{array}$ & \begin{tabular}{|c|} 
Hindustan \\
Latex \\
Family \\
Planning \\
Promotion \\
Trust \\
(HLFPPT) \\
\end{tabular} & NGO & Private & $\begin{array}{c}\text { Married Women } \\
\text { (ages 15-49), } \\
\text { Men of Bottom } \\
20 \% \text { Income }\end{array}$ & \begin{tabular}{|c|} 
SMH services, \\
FP, STI/RTI \\
Similar \\
to Agra+, \\
Ultrasound, \\
Blood Test, \\
Immunization \\
\end{tabular} & 75 & Free & Yes & Yes & $\begin{array}{c}\text { Negotiated, } \\
\text { Rates at } 35 \text { to } 50 \% \\
\text { below market prices }\end{array}$ & $\begin{array}{l}\text { Branding, } \\
\text { leaflets, house } \\
\text { visits by } \\
\text { volunteers }\end{array}$ \\
\hline 12 & $\begin{array}{l}\text { India, } \\
\text { Jharkhand }\end{array}$ & Sambhav & USAID & $\begin{array}{l}\text { Bilateral } \\
\text { Agency }\end{array}$ & $\begin{array}{l}\text { USAID, } \\
\text { State } \\
\text { Government }\end{array}$ & $\begin{array}{l}2006 \\
\text { to } 2012\end{array}$ & $\begin{array}{l}\text { Jharkhand } \\
\text { Health } \\
\text { Society, } \\
\text { Government }\end{array}$ & NGO & Private & $\begin{array}{c}\text { Married Women } \\
\text { (ages 15-49), } \\
\text { Men of Bottom } \\
20 \% \text { Income }\end{array}$ & $\begin{array}{l}\text { FP, Short and } \\
\text { Long Term } \\
\text { (only one } \\
\text { with injectable) }\end{array}$ & 2 & Free & Yes & Yes & $\begin{array}{c}\text { Negotiated, } \\
\text { Rates at } 35 \text { to } 50 \% \\
\text { below market prices }\end{array}$ & $\begin{array}{c}\text { Branding, } \\
\text { leaflets, house } \\
\text { visits by Sahiyyas }\end{array}$ \\
\hline 13 & $\begin{array}{l}\text { India, } \\
\text { Uttarakhand }\end{array}$ & Sambhav & USAID & $\begin{array}{l}\text { Bilateral } \\
\text { Agency }\end{array}$ & $\begin{array}{l}\text { USAID, } \\
\text { State } \\
\text { Government }\end{array}$ & $\begin{array}{l}2006 \\
\text { to } 2012\end{array}$ & $\begin{array}{l}\text { Uttarakhand } \\
\text { Health and } \\
\text { Family } \\
\text { Welfare } \\
\text { Society }\end{array}$ & NGO & Private & $\begin{array}{l}\text { Married Women } \\
\text { (ages 15-49), } \\
\text { Men of Bottom } \\
20 \% \text { Income }\end{array}$ & $\begin{array}{c}\text { SMH Services, } \\
\text { FP, Infant Care } \\
\text { (last probably } \\
\text { part SM) }\end{array}$ & 35 & Free & Yes & Yes & $\begin{array}{c}\text { Negotiated, } \\
\text { Rates at } 35 \text { to } 50 \% \\
\text { below market prices }\end{array}$ & $\begin{array}{c}\text { Branding, } \\
\text { leaflets, behavior } \\
\text { change } \\
\text { communication } \\
\text { by ASHAs } \\
\end{array}$ \\
\hline 14 & Kenya & RH-OBA Program & $\mathrm{kfW}$ & $\begin{array}{l}\text { Bilateral } \\
\text { Agency }\end{array}$ & $\begin{array}{c}\text { State } \\
\text { Government }\end{array}$ & \begin{tabular}{|l|}
2006 \\
to Present
\end{tabular} & Pwc & For Profit & $\begin{array}{c}\text { Private } \\
\text { and Public }\end{array}$ & $\begin{array}{c}\text { Poor Women } \\
\text { ages 15-49 } \\
\text { (WRA, pregnant), } \\
\text { GBV Services } \\
\text { (All Women) }\end{array}$ & \begin{tabular}{|c} 
Safe \\
Motherhood, \\
Long Term FP, \\
Sterilization, \\
GBV
\end{tabular} & 74 & \begin{tabular}{|c|} 
KSh. 100 \\
(US $\$ 1.25$ ) \\
for FP, \\
KSh. 200 \\
(US $\$ 2.50$ ) \\
for Safe \\
Motherhood \\
GBV Free \\
\end{tabular} & no & Yes & $\begin{array}{c}\text { Flat Rate } \\
\text { for All Services } \\
\text { (vary in districts) } \\
\text { Excluding } \\
\text { Complications }\end{array}$ & $\begin{array}{l}\text { Radio } \\
\text { commercials, } \\
\text { posters }\end{array}$ \\
\hline 15 & Kenya & Friends of Youth & $\begin{array}{l}\text { Rockefeller } \\
\text { Foundation, } \\
\text { US CDC }\end{array}$ & $\begin{array}{l}\text { Bilateral } \\
\text { Agency }\end{array}$ & $\begin{array}{l}\text { PC, } \\
\text { Family } \\
\text { Planning } \\
\text { Association } \\
\text { of Kenya } \\
\text { (FPAK) }\end{array}$ & $\begin{array}{l}1997 \\
\text { to } 2010\end{array}$ & $\begin{array}{l}\text { Family Health } \\
\text { Options } \\
\text { of Kenya } \\
\text { (FHOK), } \\
\text { formerly } \\
\text { Family } \\
\text { Planning } \\
\text { Association } \\
\text { of Kenya } \\
\text { (FPAK) } \\
\end{array}$ & NGO & Private & $\begin{array}{l}\text { Young Poor (ages } \\
10-24 \text { ) and } \\
\text { Influential Adults }\end{array}$ & SRH & 12 & $\begin{array}{l}\text { US } 50 \phi \\
\text { to } \$ 1.50\end{array}$ & No & No & $\begin{array}{c}\text { Underwritten } \\
\text { by Association and } \\
\text { Collaborating Service } \\
\text { Providers }\end{array}$ & $\begin{array}{c}\text { Group } \\
\text { discussions, role } \\
\text { playing, drama } \\
\text { and lectures by } \\
\text { FOYs }\end{array}$ \\
\hline 16 & Korea & $\begin{array}{l}\text { Korean Family } \\
\text { Planning } \\
\text { Programme }\end{array}$ & $\begin{array}{c}81 \% \\
\text { by Government, } \\
19 \% \text { by Donors } \\
\text { ( } 50 \% \text { by PC), } \\
\text { up to } 68\end{array}$ & $\begin{array}{l}\text { Bilateral } \\
\text { Agency }\end{array}$ & Government & $\begin{array}{c}1964 \\
\text { to } 1985\end{array}$ & $\begin{array}{l}\text { Planned } \\
\text { Parenthood } \\
\text { Federation } \\
\text { of Korea }\end{array}$ & $\begin{array}{c}\text { State } \\
\text { Government }\end{array}$ & Public & $\begin{array}{c}\text { Women } \\
\text { (ages 15-44) } \\
\text { and Men } \\
\text { of Reproductive } \\
\text { Age }\end{array}$ & $\begin{array}{c}\text { IUD, } \\
\text { vasectomy, } \\
\text { oral } \\
\text { contraceptives }\end{array}$ & Not Mentioned & Not Stated & No & Yes & $\begin{array}{l}15 \% \text { for IUD insertion, } \\
30 \% \text { vasectomy, } 60 \% \\
\text { to FP worker, } 40 \% \text { to } \\
\text { supervisor }\end{array}$ & $\begin{array}{c}\text { Door to door by } \\
\text { FP Field workers, } \\
\text { Mothers Clubs, } \\
\text { Happy Home FP } \\
\text { magazine, } \\
\text { Mobile teams }\end{array}$ \\
\hline 17 & Madagascar & Top Reseau & $\begin{array}{l}\text { SF funded } \\
\text { by USAID, } \\
\text { Global Fund }\end{array}$ & $\begin{array}{l}\text { Bilateral } \\
\text { Agency }\end{array}$ & PSI & \begin{tabular}{|l|}
2005 \\
to Present
\end{tabular} & Jhpiego & NGO & Private & $\begin{array}{c}\text { Youth } \\
\text { (ages 15-24), } \\
\text { Men and Women } \\
\text { of Reproductive } \\
\text { Age }\end{array}$ & $\begin{array}{c}\text { FP, } \\
\text { STIs or VCT }\end{array}$ & $\begin{array}{c}170 \\
\text { in } 173 \text { clinics }\end{array}$ & $\begin{array}{l}\text { Ar 2,000 } \\
\text { (\$1.00) } \\
\text { for UuD } \\
\text { insertion }\end{array}$ & No & Yes & $\begin{array}{l}\text { US } 75 \phi \text { to } \$ 1.00 \\
\text { per General Voucher } \\
\text { Consultation, } \\
50 \phi \text { for VCT-Specific } \\
\text { Voucher }\end{array}$ & \begin{tabular}{|c|} 
branding, \\
billboards, flyers, \\
brochures, \\
posters, radio, TV \\
and peer \\
educators \\
\end{tabular} \\
\hline 18 & Madagascar & BlueStar & $\begin{array}{l}\text { SF funded } \\
\text { by USAID }\end{array}$ & $\begin{array}{l}\text { Bilateral } \\
\text { Agency }\end{array}$ & MSI & 2011 & - & NGO & Private & $\begin{array}{c}\text { Youth } \\
\text { (ages 15-24), } \\
\text { Men and Women } \\
\text { of Reproductive } \\
\text { Age }\end{array}$ & FP & 70 & Unknown & No & $\begin{array}{l}\text { Fraud Check } \\
\text { on Small } \\
\text { Sample } \\
\text { of Vouchers }\end{array}$ & Unknown & $\begin{array}{c}\text { Bluestar } \\
\text { branding and } \\
\text { marketing. Peer } \\
\text { education in } \\
\text { community } \\
\text { distribution too. }\end{array}$ \\
\hline
\end{tabular}




\begin{tabular}{|c|c|c|c|c|c|c|c|c|c|c|c|c|c|c|c|c|c|}
\hline 19 & Myanmar & $\begin{array}{l}\text { Vouchers Sun } \\
\text { Quality Health } \\
\text { Franchise }\end{array}$ & $\begin{array}{c}\text { SF: BMGF, } \\
\text { Anonymous } \\
\text { Donor, USAID, } \\
\text { 3DF, Danish } \\
\text { Government } \\
\text { Fund, UNFPA } \\
\end{array}$ & $\begin{array}{l}\text { Bilateral } \\
\text { Agency }\end{array}$ & PSI & $\begin{array}{c}2001 \\
\text { to Present }\end{array}$ & $\begin{array}{l}\text { Sun Quality } \\
\text { Health (SQH) } \\
\text { private } \\
\text { physician } \\
\text { network }\end{array}$ & $\begin{array}{l}\text { Private } \\
\text { for Profit }\end{array}$ & Private & $\begin{array}{l}\text { FP (IUD), } \\
\text { STI Treatment } \\
\text { Discounts }\end{array}$ & $\begin{array}{l}\text { FP (IUD), } \\
\text { STI Treatment } \\
\text { Discounts }\end{array}$ & 1,579 clinics & $\begin{array}{l}\text { U\$0.050 } \\
\text { for RH,STI } \\
\text { services }\end{array}$ & No & Yes & $\begin{array}{l}41 \text { to } 95 \% \text { Subsidy } \\
\text { on Different Products }\end{array}$ & $\begin{array}{c}\text { Promotional } \\
\text { materials }\end{array}$ \\
\hline 20 & Nicaragua & $\begin{array}{l}\text { Vouchers } \\
\text { for Adolescents }\end{array}$ & $\begin{array}{c}\text { DfID, } \\
\text { Dutch } \\
\text { Government, } \\
\text { USAID }\end{array}$ & $\begin{array}{l}\text { Bilateral } \\
\text { Agency }\end{array}$ & ICAS & $\begin{array}{l}2000 \\
\text { to } 2005\end{array}$ & ICAS & NGO & $\begin{array}{c}\text { Public } \\
\text { and Private }\end{array}$ & Poor Adolescents & \begin{tabular}{|c|} 
SRH: \\
Counseling, FP, \\
Pregnancy \\
Test, First \\
Pregnancy \\
RTIs/STIs
\end{tabular} & $\begin{array}{l}35 \text { Total: } \\
20 \text { Managua, } \\
10 \text { Chinand, } \\
5 \text { Rivas }\end{array}$ & Free & No & & Flat Rate & $\begin{array}{c}\text { Adolescents } \\
\text { talked to } \\
\text { at markets, } \\
\text { near schools, } \\
\text { house-to-house } \\
\text { in barrios }\end{array}$ \\
\hline 21 & Pakistan MSI & $\begin{array}{l}\text { Suraj Private } \\
\text { Provider } \\
\text { Partnership }\end{array}$ & $\begin{array}{l}\text { Anonymous } \\
\text { Donor }\end{array}$ & $\begin{array}{l}\text { Bilateral } \\
\text { Agency }\end{array}$ & MSI & $\begin{array}{l}2008 \\
\text { to } 2012\end{array}$ & $\begin{array}{l}\text { MSS, } \\
\text { MSI }\end{array}$ & NGO & Private & $\begin{array}{l}\text { Low Income } \\
\text { Rural Women }\end{array}$ & $\begin{array}{l}\text { IUCD Insertion, } \\
\text { Follow Up, } \\
\text { Removal }\end{array}$ & 100 & Free & Yes & Yes & $\begin{array}{l}200 \text { per Provider: } \\
\text { Insertion (150), } \\
\text { Follow Up (20), } \\
\text { Removal (30) } \\
\end{array}$ & $\begin{array}{l}\text { Household visits } \\
\text { and counseling } \\
\text { by CHWs }\end{array}$ \\
\hline 22 & Pakistan & $\begin{array}{l}\text { Sehat Sahulat } \\
\text { Card (SSC) }\end{array}$ & $\begin{array}{l}\text { District } \\
\text { Governments } \\
\text { of Kasur and } \\
\text { Rawalpindi }\end{array}$ & National & $\begin{array}{c}\text { Contech } \\
\text { International }\end{array}$ & $\begin{array}{c}2009 \\
\text { to Present }\end{array}$ & $\begin{array}{c}\text { Zahanat } \\
\text { Foundation }\end{array}$ & NGO & Private & $\begin{array}{l}\text { Underprivileged } \\
\text { Pregnant } \\
\text { Women, } \\
\text { Children Under } \\
\text { Five Years Old } \\
\end{array}$ & $\begin{array}{l}\text { ANC, Delivery, } \\
\text { PNC }\end{array}$ & 100 & - & Yes & - & 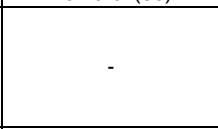 & - \\
\hline 23 & $\begin{array}{l}\text { Pakistan, } \\
\text { DG Khan, } \\
\text { Punjab }\end{array}$ & $\begin{array}{c}\text { Greenstar Voucher } \\
\text { in DG Khan, } \\
\text { Punjab }\end{array}$ & USAID & $\begin{array}{l}\text { Bilateral } \\
\text { Agency }\end{array}$ & Greenstar & $\begin{array}{l}2008 \\
\text { to } 2009\end{array}$ & Greenstar & NGO & Private & $\begin{array}{c}\text { Poor pregnant } \\
\text { Women } \\
\text { in DG Khan, } \\
\text { Jhang, Sindh } \\
\text { (Badin and } \\
\text { Shikarpur). }\end{array}$ & $\begin{array}{c}\text { SMH } \\
\text { (Deliveries, } \\
\text { ANC, PNC), } \\
\text { FP }\end{array}$ & 22 & $\$ 1.20$ & Yes & $\begin{array}{l}\text { In DG Khan, } \\
\text { Identification } \\
\text { for selection } \\
\text { of women to } \\
\text { join voucher } \\
\text { scheme } \\
\text { verified } \\
\text { by elected } \\
\text { Union council }\end{array}$ & $\begin{array}{l}\text { FFS Scheme } \\
\text { with Same Fees for All }\end{array}$ & $\begin{array}{l}\text { Lady Health } \\
\text { Visitors }\end{array}$ \\
\hline 24 & $\begin{array}{l}\text { Pakistan, } \\
\text { Jhang, } \\
\text { Punjab }\end{array}$ & $\begin{array}{l}\text { Greenstar Voucher } \\
\text { in Jhang district, } \\
\text { Punjab }\end{array}$ & PSI & $\begin{array}{l}\text { Bilateral } \\
\text { Agency }\end{array}$ & Greenstar & $\begin{array}{c}2009 \\
\text { to } 2012\end{array}$ & Greenstar & NGO & Public & $\begin{array}{l}\text { Poor Pregnant } \\
\text { Women }\end{array}$ & $\begin{array}{c}\text { SMH } \\
\text { Including FP }\end{array}$ & 29 & $\$ 1.20$ & Yes & $\begin{array}{c}\text { Sample } \\
\text { household } \\
\text { verification } \\
\text { survey } \\
\text { by external } \\
\text { research } \\
\text { agency } \\
\end{array}$ & Flat Rate & $\begin{array}{l}\text { Field workers } \\
\text { market vouchers }\end{array}$ \\
\hline 25 & \begin{tabular}{|} 
Pakistan KfW \\
(Charsadda \\
district \\
in KP \\
province)
\end{tabular} & Greenstar III & $\mathrm{KfW}$ & $\begin{array}{l}\text { Bilateral } \\
\text { Agency }\end{array}$ & & $\begin{array}{l}2010 \\
\text { to } 2011\end{array}$ & & & Private & Poor Women & $\begin{array}{c}\text { SMH, FP } \\
\text { Within SMH } \\
\text { Services }\end{array}$ & & & & & & $\begin{array}{l}\text { Door to door } \\
\text { visits }\end{array}$ \\
\hline 26 & Sierra Leone & $\begin{array}{l}\text { Healthy Life, } \\
\text { Healthy Baby }\end{array}$ & MSI & $\begin{array}{l}\text { Bilateral } \\
\text { Agency }\end{array}$ & MSI & 2009 & MSI & NGO & Private & $\begin{array}{l}\text { Poor Pregnant } \\
\text { Women, } \\
\text { Poor WRAs }\end{array}$ & $\begin{array}{c}\text { FP(LAPM), } \\
\text { SMH (ANC, } \\
\text { delivery, } \\
\text { ultrasound, } \\
\text { PNC with FP) }\end{array}$ & 20 & & No & Exit Interviews & Flat Rate & \\
\hline 27 & Taiwan & $\begin{array}{l}\text { Taiwan Population } \\
\text { Studies Center } \\
\text { Coupon System }\end{array}$ & $\begin{array}{l}\text { USAID, } \\
\text { PC }\end{array}$ & $\begin{array}{l}\text { Bilateral } \\
\text { Agency }\end{array}$ & Government & $\begin{array}{c}1964 \\
\text { to } 1985\end{array}$ & $\begin{array}{l}\text { Taiwan } \\
\text { Provincial } \\
\text { Institute } \\
\text { of Family } \\
\text { Planning, } \\
\text { Ministry } \\
\text { of Health } \\
\end{array}$ & Government & $\begin{array}{c}\text { Public } \\
\text { and Private }\end{array}$ & $\begin{array}{c}\text { Couples Needing } \\
\text { FP }\end{array}$ & $\begin{array}{c}\text { IUD, } \\
\text { Sterilization }\end{array}$ & $\begin{array}{l}800 \text { Clinics } \\
\text { for BTC+VS }\end{array}$ & Free & No & $\begin{array}{l}\text { After } 2 \text { to } 3 \\
\text { Months, } \\
\text { Field Worker } \\
\text { Checks } \\
\text { if Coupon Used }\end{array}$ & Subsidy & $\begin{array}{l}\text { mass media, } \\
\text { group education } \\
\text { in schools and } \\
\text { markets, group } \\
\text { education }\end{array}$ \\
\hline 28 & $\begin{array}{l}\text { Uganda } \\
\text { KfW } \\
\text { GPOBA }\end{array}$ & $\begin{array}{l}\text { Healthy Life, } \\
\text { Healthy Baby } \\
\text { Family Planning } \\
\text { Voucher Project }\end{array}$ & $\begin{array}{c}\text { KfW, } \\
\text { Government } \\
\text { of Uganda, } \\
\text { World Bank } \\
\text { Global } \\
\text { Partnership } \\
\text { for Output-Based } \\
\text { Aid }\end{array}$ & $\begin{array}{l}\text { Bilateral } \\
\text { Agency }\end{array}$ & $\begin{array}{c}\text { KfW, } \\
\text { GPOBA- } \\
\text { MSI } \\
\text { implemented }\end{array}$ & $\begin{array}{l}2006 \\
\text { to } 2012\end{array}$ & MSI & NGO & Private & $\begin{array}{l}\text { Poor Women } \\
\text { and Men }\end{array}$ & $\begin{array}{l}\text { STI Treatment, } \\
\text { ANC, Delivery, } \\
\text { PNC }\end{array}$ & 130 & $\begin{array}{c}\text { Healthlife } \\
1500 \text { Ush } \\
\text { (US 75\$), } \\
\text { Healthy } \\
\text { Baby } \\
3,000 \text { Ush } \\
\text { (US \$1.50) }\end{array}$ & No & Yes & $\begin{array}{l}\text { Flat Rate, } \\
\text { Not Specified }\end{array}$ & $\begin{array}{c}\text { Radio talk } \\
\text { shows, program } \\
\text { announcements, } \\
\text { meetings, } \\
\text { FP brochures, } \\
\text { community } \\
\text { sessions, } \\
\text { mobile cinema, } \\
\text { posters, flyers, } \\
\text { leaflets } \\
\end{array}$ \\
\hline
\end{tabular}




\begin{tabular}{|c|c|c|c|c|c|c|c|c|c|c|c|c|c|c|c|c|c|}
\hline 29 & Vietnam & BlueStar Vietnam & $\begin{array}{l}\text { MSI, AusAID, } \\
\text { IPPF }\end{array}$ & $\begin{array}{l}\text { Bilateral } \\
\text { Agency }\end{array}$ & MSI & $\begin{array}{l}2008 \text { to } \\
\text { Present }\end{array}$ & MSI & NGO & $\begin{array}{c}\text { Public } \\
\text { and Private }\end{array}$ & Poor People & \begin{tabular}{|c|} 
Access to \\
Gynecological \\
Exam and \\
Cervical cancer \\
Check Through \\
Visual \\
Inspection by \\
Acid Acetic \\
(VIA), IUD, Safe \\
Medical \\
Abortion \\
\end{tabular} & 299 & Free & - & Yes & Subsidy & $\begin{array}{l}\text { information was } \\
\text { disseminated by } \\
\text { community } \\
\text { health care } \\
\text { workers and } \\
\text { Bluestar website } \\
\text { and call centres }\end{array}$ \\
\hline 30 & Vietnam & $\begin{array}{l}\text { Tinh Chiem } \\
\text { (Sisterhood) }\end{array}$ & $\begin{array}{c}\text { European } \\
\text { Commission, } \\
\text { Atlantic } \\
\text { Philanthropies }\end{array}$ & $\begin{array}{l}\text { Multilateral } \\
\text { Agency }\end{array}$ & MSI & $\begin{array}{l}2007 \\
\text { to Present }\end{array}$ & - & - & $\begin{array}{c}\text { Public } \\
\text { and Private }\end{array}$ & $\begin{array}{l}\text { Young Adults } \\
\text { (ages 13-24), } \\
\text { Men, Women }\end{array}$ & $\begin{array}{l}\text { Cervical and } \\
\text { Breast Cancer } \\
\text { Screening, } \\
\text { Safe Abortion, } \\
\text { FP (IUD) } \\
\end{array}$ & 181 & - & & - & - & $\begin{array}{l}\text { Branding and } \\
\text { brand } \\
\text { ambassadors }\end{array}$ \\
\hline 31 & Zambia & $\begin{array}{l}\text { Zambian } \\
\text { Contraceptive } \\
\text { Access Study } \\
\text { (ZCAS) }\end{array}$ & $\begin{array}{l}\text { National Science } \\
\text { Foundation, } \\
\text { Hewlett } \\
\text { Foundation, } \\
\text { Women \& Public } \\
\text { Policy Program } \\
\text { at Harvard } \\
\end{array}$ & $\begin{array}{l}\text { Multilateral } \\
\text { Agency }\end{array}$ & SFH & $\begin{array}{l}2006 \\
\text { to } 2007\end{array}$ & SFH & NGO & Public & $\begin{array}{c}\text { Married Women } \\
\text { (ages 18-40) } \\
\text { in One Low } \\
\text { Income Urban } \\
\text { Area }\end{array}$ & $\begin{array}{l}\text { Implants, } \\
\text { Injectables }\end{array}$ & 1 & Free & No & Yes & N/A & No \\
\hline 32 & Zambia & $\begin{array}{c}\text { Vouchers } \\
\text { for Sexual and } \\
\text { Reproductive } \\
\text { Health for Young } \\
\text { People } \\
\text { Participating } \\
\text { in a Youth } \\
\text { Programme } \\
\end{array}$ & DfID & $\begin{array}{l}\text { Bilateral } \\
\text { Agency }\end{array}$ & PC & 2012 & $\mathrm{PCl}$ & NGO & $\begin{array}{c}\text { Public } \\
\text { and Private }\end{array}$ & Adolescent Girls & $\begin{array}{c}\text { General Health, } \\
\text { FP }\end{array}$ & & Free & & & N/A & \\
\hline
\end{tabular}




\section{Discussion}

Evidence on the effectiveness of vouchers for contraceptive products and services has largely focused on metrics for contraceptive use, the reported outcomes of which this review found most to be positive and statistically significant. The one study of fertility in Taiwan from 1969 found a positive and significant decrease in fertility of voucher acceptors compared to a similar group of women matched on age and parity. A voucher is a useful means for tallying contraceptive service visits to determine utilization outcomes. It is not surprising that nearly all studies reported on changes in utilization and most studies found a significant and positive improvement in contraceptive utilization.

The literature is largely consistent on utilization outcomes; there are, however, missing metrics on other dimensions of performance and failure to synthesize insights from program operations. Discontinuation is an important but underreported area. One Pakistan study found IUD discontinuation the same in voucher and non-voucher populations but offered no numbers, and no other study has reported on this outcome (Azmat et al. 2012).

Aside from one study in Nicaragua on simulated clients receiving their preferred methods in a before-and-after design, no studies report on supply side effects of FP vouchers, which are critical to successful service delivery. The FP voucher, with its quality assurance mechanisms and financial reimbursement for service delivery, is an underappreciated strategy for addressing supply side challenges.

Synthesis of findings from program operations is beyond the scope of this review, but would be a valuable contribution to the literature. The Marie Stopes experience in Madagascar included a small follow up on 65 voucher clients and found two vouchers issued at a Bluestar facility, contrary to program requirements for voucher distribution to beneficiaries in the community (Kemplay et al. 2013). That study's results were not sufficiently rigorous to meet this review's inclusion criteria, but the findings would be of interest in a scoping review of program design and functionality. Another programmatic area for inclusion in future scoping reviews is the unused percentage of distributed FP vouchers. Several reports present data on non-use but do not present before-and-after results, time trends, or a comparison to alternative forms of community outreach to determine whether non-use of some percentage in that programmatic context was above or below a given standard.

\section{LIMITATIONS}

Although this review found largely positive effects, there are limitations to consider when synthesizing the results. In screening search results, this review found 31 contraceptive voucher programs; however, only 13 had one or more studies (see Table 4 for a list of identified FP voucher programs). As the publication years indicate, most studies were published after 2000. Many early voucher programs in the 1960s and 1970s were not well documented and could not be included in this review, a limitation that has been noted elsewhere.

Of the 21 study outcomes in 15 source reports, 13 outcomes were reported from before-and-after or cross sectional designs. These are weak designs that offer little ability to attribute causation. Even CBAs cannot control for potential unobserved confounders. Albeit weak, the study designs did provide a consistent story with the direction and significance of positive effect. Such evidence, however weak, indicates a need for further research with better designs.

Another limitation was the lack of disaggregated outcomes by provider type. Private and public providers could respond differently to reimbursements for FP voucher services. Studies failed to report results from sub-group analysis, however. 


\section{POLICY IMPLICATIONS}

In spite of these limitations, this review has yielded important information on the effectiveness of voucher programs subsidizing contraceptive products and services. Voucher programs are intended to target subsidies to beneficiaries who, in the subsidy's absence, would have lower probabilities of service utilization. In most studies, beneficiaries were defined by economic status; in two programs adolescents were identified as disadvantaged and provided vouchers. This review found that contraceptive uptake did increase among targeted beneficiaries in most studies.

Vouchers demonstrate a productive mechanism for governments to engage private providers. Of the 31 programs identified during this review, 18 contracted only private providers, while seven other programs contracted a mix of public and private providers, and six programs engaged only public providers. The results suggest that voucher programs can expand client choice by reducing financial barriers to contraceptive services and make private providers an option for disadvantaged clients previously restricted by cost.

\section{FUTURE DIRECTIONS}

Future research is needed to focus on both supply- and demand side outcomes. Equally important, research is needed to explore how variation in program design can impact outcomes. Promising areas for future research demand side, supply side, and policy issues:

\section{Demand Side Questions}

1. Do voucher programs influence users of less effective contraceptive methods to switch to more effective long term methods?

2. What are voucher programs' effects on contraceptive uptake and contraceptive continuation rates?

3. Is the introduction of vouchers associated with improved continuation rates?

4. What should be the minimum duration of voucher interventions for a sustainable change in contraceptive behavior?

5. Is a single method FP voucher more effective than a comprehensive voucher for contraceptive uptake?

6. Do contraceptive vouchers programs introduce acceptance (acquiescence) bias?

7. Are expiration dates associated with improved uptake of distributed FP vouchers?

8. Which FP voucher program distribution strategies are associated with reaching the greatest proportion of the poorest 40 percent, within specific countries?

9. Is there a significant difference in FP voucher uptake among the bottom two quintiles and adolescents when vouchers are sold rather than distributed for free?

10. Is there any effect of voucher interventions on FP-related health outcomes such as changes in FP methods? Does this have an impact on patient choice or lead to coercion?

11. Are free (i.e. fully subsidized) contraceptives less valued by clients than partially subsidized or unsubsidized contraceptives?

\section{Supply Side Questions}

1. What is the level of suspected fraud and waste in FP voucher programs?

2. Does competition among facilities (or $\mathrm{CHWs} / \mathrm{CBDs}$ ) increase after introducing an FP voucher program?

3. Does patient satisfaction with FP services change after the introduction of a FP voucher program?

4. What happens to provider behavior after the removal of a FP voucher program?

5. Do voucher programs have any influence on health worker performance, service delivery, and quality in FP? If so, how? How can payments and targets be set more efficiently?

6. What is the influence of vouchers on quality of services and the right to choose desired contraceptives? 


\section{Policy Questions}

1. What is the cost-effectiveness of FP voucher programs?

2. What is the role of vouchers when FP methods are provided at no or little cost?

3. What type of provider mix is optimal in voucher programs for contraceptive uptake?

4. How do vouchers support women's empowerment?

5. What can strengthen male involvement in FP voucher programs?

\section{FUNDING}

The evidence synthesis upon which this article was based was funded by World Health Organization and the Evidence project (USAID-funded).

The funders played no role in study design, collection, analysis, data interpretation, report writing, or in the decision to submit the paper for publication.

\section{AUTHOR CONTRIBUTIONS}

Ben Bellows drafted the research protocol, discussed the scope of the review with Dr. Bajracharya, with substantial contributions to the concept and design, led the acquisition of data and its analysis and interpretation, and participated in multiple rounds of the manuscript draft.

Ashish Bajracharya drafted the research protocol, discussed the scope of the review with Dr. Bellows, made substantial contributions to the concept and design, participated in analysis and interpretation of the data, and participated in multiple rounds of the manuscript draft.

Carol Bulaya implemented the search strategy process, provided suggestions on iterations of the search, screened articles in consultation with Ms. Inambwae, and drafted early versions of the report.

Sophie Inambwae implemented the search strategy process, provided suggestions on iterations of the search, screened articles in consultation with Carol Bulaya, and drafted early versions of the report. 


\section{References}

Agha, S. 2011. Changes in the Proportion of Facility-based Deliveries and Related Maternal Health Services Among the Poor in Rural Jhang, Pakistan: Results from a Demand-side Financing Intervention. International Journal for Equity in Health 10(57). doi:10.1186/1475-9276-10-57.

Ashraf, N., M. Buessing, E. Field, J. Leight. 2014. The Psycho-Social Benefits of Access to Contraception: Experimental Evidence from Zambia.

Azmat, S.K., S. Khurram Azmat, B.T. Shaikh, B. Tasneem Shaikh, W. Hameed, G. Mustafa, W. Hussain, J. Asghar, M. Ishaque, A. Ahmed, M. Bilgrami. 2013. Impact of Social Franchising on Contraceptive Use when Complemented by Vouchers: A Quasi-Experimental Study in Rural Pakistan. PloS One 8, e74260. doi:10.1371/journal.pone.0074260.

Bajracharya, A., L. Veasnakiry, T. Rathavy, B. Bellows. 2015. The Impact of a Reproductive Health Voucher Program on Increasing Uptake of Long Acting Reversible Contraceptives (LARC) in Cambodia: Evidence from a Difference-in-Differences Analysis.

BlueStar Vietnam. n.d. http://healthmarketinnovations.org/program/bluestar-vietnam, Accessed 9 April 2015.

Boler, T., L. Harris. 2010. Reproductive Health Vouchers.

Chin-Quee, D.S., M. Wedderburn, C. Otterness, B. Janowitz, M. Chen-Mok. 2010. Bridging Emergency Contraceptive Pill Users to Regular Contraception: Results from a Randomized Trial in Jamaica. Contraception 81: 133-139.

Cleland, J., S. Bernstein, A. Ezeh, A. Faundes, A. Glasier, J. Innis. 2006. Family Planning: The Unfinished Agenda. The Lancet 368: 1810-1827.

Effective Practice and Organisation of Care (EPOC). 2013. Summary Assessments of the Risk of Bias. EPOC Resources for Review Authors. Oslo: Norwegian Knowledge Centre for the Health Services. http://epoc.cochrane.org/epoc-specific-resources-review-authors.

IFPS Technical Assistance Project (ITAP), F.G., ITAP. 2012. Sambhav: Vouchers Make High-Quality Reproductive Health Services Possible for India's Poor. http://healthmarketinnovations.org/program/sambhav-vouchersystem, Accessed 9 April 2015.

Janisch, C.P., M. Albrecht, A. Wolfschuetz, F. Kundu, S. Klein. 2010. Vouchers for Health: A Demand Side Output-based Aid Approach to Reproductive Health Services in Kenya. Global Public Health 5: 578-594. doi:10.1080/17441690903436573

Kemplay, M. n.d. Madagascar program profile. POPLINE.org. www.popline.org/node/566847, Accessed 2 April 2015.

Meuwissen, L.E., A.C. Gorter, A.D. Kester, J.A. Knottnerus. 2006a. Does a Competitive Voucher Program for Adolescents Improve the Quality of Reproductive Health Care? A Simulated Patient Study in Nicaragua. BMC Public Health 6(204).

Meuwissen, L.E., A.C. Gorter, J.A. Knottnerus. 2006b. Impact of Accessible Sexual and Reproductive Health Care on Poor and Underserved Sdolescents in Managua, Nicaragua: A Quasi-Experimental Intervention Study. Journal of Adolescent Health 38: 56-e1.

Meuwissen, L.E., A.C. Gorter, J.A. Knottnerus. 2006c. Perceived Quality of Reproductive Care for Girls in a Competitive Voucher Programme. A Quasi-Experimental Intervention Study, Managua, Nicaragua. International Journal for Quality in Health Care 18: 35-42, doi:10.1093/intqhc/mzi073

Meuwissen, L.E., A. C. Gorter, Z. Segura, A.D. Kester, J.A. Knottnerus. 2006d. Uncovering and Responding to Needs for Sexual and Reproductive Health Care Among Poor Urban Female Adolescents in Nicaragua. Tropical Medicine and International Health 11: 1858-1867. 
Obare, F., C. Warren, R. Njuki, T. Abuya, J. Sunday, I. Askew, B. Bellows. 2013. Community-level Impact of the Reproductive Health Vouchers Programme on Service Utilization in Kenya. Health Policy and Planning 28: 165-175.

Population Services International. 2011. Social Franchise Case Study: Madagascar's Top Réseau Network.

Tunisia, O.N.. n.d. Household distribution of contraceptives. POPLINE.org. www.popline.org/node/549638, Accessed 2 April 2015. 



\section{POPULATION \\ COUNCIL \\ Ideas. Evidence. Impact.}

(:) USAID

\section{Evidence}

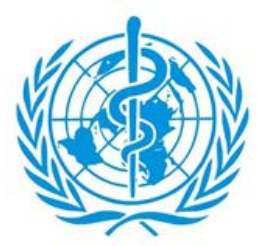

Plot 3670, Four Mwaleshi Road Lusaka, Zambia 10101 